\title{
A Phenomenological Study of Therapists' Co-transference Experiences in Sandplay Therapy ${ }^{*}$
}

\author{
Kowen, Mee Ra*
}

\begin{abstract}
$<$ Abstract $>$
In this study, we examined the co-transference experiences of sandplay therapists. We applied the descriptive phenomenological method developed by Amedeo Giorgi. To begin with, we interviewed seven therapists and analyzed the data. Of the 800 semantic units identified, we used 540 of them, excluding the repetitive, or those deviating from context. By comparing these items, we identified 116 meanings. We structured three components and 10 sub-components based on the central meanings. The components comprised the co-transference experience, while the sub-components contained 48 semantic units. In our interviews, we noted that the participants were placing their clients' sand scenes in the center of their statements. Thus, the pairs had fused with the sand trays and healed each other's wounds. The total structure of empathy and healing made up co-transference.
\end{abstract}

Keywords : sandplay therapy, sandplay therapist, co-transference, transference, archetype

* This paper is a supplement and revision on 2019 doctoral dissertation at Namseoul University.

** Director of Ribbon Psychological Counseling Center (kowen0808@naver.com) 
Journal of Symbols \& Sandplay Therapy, Vol.11 No.2.

\section{INTRODUCTION}

\section{A. Research Purpose and Necessity}

Sandplay therapy is a form of in-depth psychotherapy in which one can briefly stay away from rationality and express oneself in a silent journey. By pacifying the conscious mind, it provides an opportunity for unconscious expression (Steninhard, 2013). When a client creates a sandpicture, the therapist witnesses the symbols that appear in that creative world. The therapeutic relationship between the client and the therapist, or the experience of co-transference in sandplay therapy sessions, enables the coordination of the meaning of symbols, which leads to healing (Jang, 2017).

Psychotherapy that is based on analytical psychology involves a dynamic interaction between the therapist and client in the fields of relationship, interaction (Jacoby, 1990) and intersubjectivity (Stolorow \& Atwood, 1992). In transference psychology, Jung (1966) described the therapeutic relationship between the therapist and client as a conscious and unconscious interaction of two people, interacting with each other in the container of alchemy. This view expands the concept of interaction in psychotherapy into a larger and more complex concept of interaction in an unconscious and archetypal relationship of transference and counter-transference (Friedman \& Michell, 2007). It brings together transference and counter-transference into a single concept of co-transference.

The therapeutic relationship in sandplay therapy is related to the projection between therapist and client. Client's projection onto the therapist involves not only the client's feelings from the past and the present but also the therapist's experiences of the past and the present. In that sense, co-transference is the therapeutic feeling relationship that "embraces a feeling with (co), rather than a feeling against (counter)" (Bradway, 1991). When the unconscious in the inner world is activated in the sandpicture, an intuitive link is formed between the therapist and the client and they encounter a moment of deep recognition and unverbal knowing (Kalff, 1980). Before the term co-transference was coined, Kalff called it as the "synchronistic moment" and viewed this as the "ultimate therapeutic moment" in sandplay therapy (Bradway \& McCoard, 1997). At this time, a deep unconscious bond between the two manifests as the 
client's internal transformation (Montecchi, 1991). While transference and counter-transference occur sequentially, co-transference is about an unconscious therapist-client bond that is formed almost simultaneously and instantaneously. Co-transference is accompanied by images in which the repressed aspects of the psyche or individual memory emerge as a symbol of archetypes (Montecchi, 1991).

Contemporary psychotherapy is undergoing a paradigm shift in which the focus on the left brain is moving to the right brain (Schore, 2003). This represents a shift from a cognitive approach to an emotional approach and stresses the importance of co-transference, which is the emotional within the therapeutic relationship through which the client's past traumatic experiences are simultaneously experienced by the therapist (Schore, 2012). Therapist's deep understanding of the unconscious and the emotional sensitivity of the right brain function within the therapist-client relationship as a genuine therapeutic tool (Stern, 2008). Through the experience of co-transference within the therapeutic relationship, the sandplay therapist "listens" to the client's emotional state.

As mentioned above, co-transference is indispensable to the formation of a therapeutic relationship in sandplay therapy. However, supervisions and case studies generally focus on clients' psychic dynamics when interpreting and analyzing sandpictures so as to provide useful context for therapy. In doing so, the special feelings or strong transference that therapists may experience in therapy are not fully addressed. And because therapist themselves also perceive being immersed in their own emotional state as negative counter-transference, it has been difficult to examine feelings of transference at a deep level. This research therefore intends to approach the essential meaning of co-transference experience through in-depth interviews with sandplay therapists as research participants.

Existing studies in Korea on therapeutic relationships mainly focus on therapists' counter-transference experiences. Many of them saw the experiences of counter-transference as being conducive to therapy (Choi, 2005; Lim \& Kim, 2008; Hwang, 2005; Lee, 2010; Kim \& Kim, 2007; Kim \& An, 2013; Choi \& Lee, 2009). On the other hand, no studies on the therapeutic relationship of co-transference can be found in Korea. Thus if the topic of co-transference is dealt with in the area of sandplay therapy through this study, it would 
Journal of Symbols \& Sandplay Therapy, Vol.11 No.2.

promote wider discussion on transference.

Sandplay therapy focuses on gaining a symbolic understanding of the client's emotions linked to preverbal trauma through an in-depth analysis of the sandbox and the therapy process. It also places importance on treating the world beyond the conscious, such as the unconscious and archetype (Turner, 2004). To grasp the fundamental meaning of co-transference, or the therapeutic relationship linked to the domain of the unconscious, it is imperative to listen to the real voices of therapists and look into the phenomenon itself. Therefore, a phenomenological study is deemed to be the most proper approach.

The purpose of this study is to use Amedeo Giorgi's phenomenological research method to gain a fundamental understanding of the specific co-transference experience that sandplay therapists go through, with an intention to overcome the limits of quantitative or psychophysical research (Giorgi, 1985). Co-transference is a direct and real phenomenon that interacts and changes within a therapeutic relationship. Therefore, it is difficult to understand the nature of co-transference through a conceptual or causational natural scientific approach. Rather than approaching a psychological phenomenon as a physical subject, a descriptive phenomenological study seeks to explore the fundamental meaning of the very experience that a subject goes through without any premises or manipulation (Giorgi, 1985). This study aims to stay away from studying a psychological phenomenon with a quantitative or scientific attitude and instead take a more natural, or phenomenological, approach.

In sandplay therapy, in which the conscious and unconscious meet, the phenomenon of co-transference, or the communication between the right brain of the client and the right brain of the therapist (Schore, 2003), and a connection of the unconscious and unconscious (Jung, 1966), is an important factor in establishing a therapeutic relationship, and has a significant effect on the outcome of the in-depth psychotherapy (Bradway, 1991). The sandplay therapist encounters a client who is creating a sandpicture and feels a sense of awe, profoundly empathizes with the inner pains that cannot be expressed in words, and is infected by the client's transference, falling into a state of unconscious confusion. The sandplay therapist who experiences co-transference knows that co-transference, an archetypal union and valuable integration, brings change in the therapeutic relationship and enables healing. However, as a 
psychological phenomenon, the nature of this vague event is difficult to generalize and identify, and doubts about the fundamental meaning of the phenomenon still exist.

This study takes a phenomenological and qualitative approach in tracing the direction taken by the sandplay therapist's consciousness in a co-transference experience, with an aim to understand the nature of this pure and fundamental experience. The study involves a qualitative research method that looks into a phenomenon's specific nature, rather than an empirical view. More specifically, it adopts Giorgi's phenomenological study method, which focuses on describing the meaning and nature of an experience. The purpose of this study is to construct a fundamental meaning of the experience by exploring and structuralizing co-transference that occurs between the sandplay therapist and client in the field of consultation.

\section{B. Research Questions}

This study explores the nature of the co-transference experience that sandplay therapists go through in sandplay therapy sessions by applying Giorgi's descriptive phenomenological method. The purpose of the study is to gain a fundamental understanding of the phenomenon by carrying out a phenomenological study and taking a more practical and comprehensive approach to the research participants' experiences.

To attain this purpose, the study will address the following research questions:

1. What kind of experience is co-transference to a therapist in sandplay therapy?

2. What is the meaning of the nature of co-transference experienced by sandplay therapists?

\section{П. RESEARCH METHOD}

\section{A. Method of Phenomenological Study}

This study employs Giorgi's phenomenological study, a qualitative research method that focuses on arriving at a description of the meaning and nature of an experience. Giorgi is an 
Journal of Symbols \& Sandplay Therapy, Vol.11 No.2.

American psychologist who inherited Husserl's study of phenomenology and instituted psychological phenomenology as a qualitative research method in social science (Tesch, 1990). Giorgi was originally a psychophysics expert who based his studies on the quantitative research method. But when he realized the limits of the quantitative research method and psychophysics, he developed the phenomenological experience research method and pioneered phenomenological psychology (Giorgi, 1985). He said that while the nature of a subject in a philosophical phenomenological study is 'universal,' the nature of the subject in a psychological phenomenological study as a human science is 'more categorical and general than universal' (Giorgi, 1985. p. 78).

Phenomenology is made up of various qualitative research methodologies. The two dominant ones are Giorgi's descriptive phenomenology and van Manen's interpretive phenomenology (Lee, 2007). While interpretive phenomenology focuses on discovering the self-reflective and existent aspects of a phenomenon, Giorgi focused on the description of the nature of a phenomenon, as it appears in the human consciousness, leading to his development of descriptive phenomenology.

Human beings subjectively interpret and give meaning to their experiences. Therefore, an experience can be seen in a new light through individual and idiographic descriptions (Kim et al., 1999). This epistemic and ontologic view does not take a dichotomous approach on the subject and object, observer and research subject, or human beings and the society. Instead, it emphasizes the independent and holistic aspect of the human being, which involves making interactions in the world of everyday life, making sense of their experiences and giving them new form. In their study of human experiences, phenomenological researchers study the phenomena that human beings, made up of all complexity of perception and judgment, experience. By arriving at a description of the personal meaning of the experiences, they can comprehend the research subjects in their existence and help them (Kim et al., 1999).

A phenomenological study begins with a description of another person's experience. Giorgi believed that the most crucial part of comprehending a human phenomenon is the description. To him, interpretation was secondary. According to him, a researcher who seeks to understand the nature of a phenomenon should not merely transcribe the language used by the research 
participant but interpret it and reduce it to a description that fits the study's purpose. He saw this as a form of description. In short, his view was that observation of the matter at hand should come before the interpretation (Giorgi, 1985). Description is a process of information analysis based on a systematic process, from key testimonies, which are the narrow units of analysis, to semantic units, which are the broader units of analysis. It also involves summarized and detailed descriptions of the research participants' experiences, and how they went through the experience (Moustakas, 1994).

The researcher of this study will focus on gaining an understanding of the co-transference experience in sandplay therapy and how the research participant, or the sandplay therapist, experiences co-transference. In line with Giorgi's phenomenological experience study, the researcher will go directly into the environment that is to be studied (Kim et al., 1996), collect data within that environment and accumulate information to observe and understand the research subject.

The co-transference experience of sandplay therapists, which is what this study seeks to explore, is a phenomenon with individual and subjective qualities. It reveals human personality as individuals and, therefore, a quantitative study that involves scientific quantifications will be insufficient. This study will thus apply the phenomenological qualitative research method to come up with a description of the co-transference experience and look into its fundamental structure.

\section{B. Research Participants}

\section{Selection process}

Seven thirty-to-sixty-year-old sandplay therapists were selected to participate in the study, in accordance with the sampling principles and processes of qualitative research. The selected participants were capable of providing in-depth descriptions of their experience of the topic, and their honest and forthcoming attitude was another factor that led to vibrant testimonies.

\section{Characteristics of participants}

The general characteristics of the seven research participants are shown in Table 1: 
Journal of Symbols \& Sandplay Therapy, Vol.11 No.2.

Table 1. General Characteristics of the Research Participants

\begin{tabular}{|c|c|c|c|}
\hline Participant No. & Gender / Age & Years of Experience & Education / Major \\
\hline Participant 1 & F / 64 & 14 years & Master's course completed/Counseling \\
\hline Participant 2 & $\mathrm{~F} / 38$ & 12 years & Master's degree/Family counseling \\
\hline Participant 3 & F / 39 & 7 years & Master's degree/Counseling psychology \\
\hline Participant 4 & F / 56 & 15 years & Master's degree/ Counseling psychology \\
\hline Participant 5 & $\mathrm{~F} / 30$ & 6 years & counseling, psychotherapy \\
\hline Participant 6 & $\mathrm{~F} / 39$ & 15 years & counseling, psychotherapy \\
\hline Participant 7 & $\mathrm{~F} / 36$ & 13 years & counseling, psychotherapy \\
\hline
\end{tabular}

\section{Data Collection and Analysis}

\section{Data collection method and procedure}

To ensure the sufficiency of the study, no limits were placed on the number of participant cases during the recruitment process. A total of seven participants were selected, and based on their individual cases, the meaning of the nature of the co-transference experience in sandplay therapy was derived.

The recruitment process lasted from October to November 2018. From November 2018 to July 2019, in-depth interviews were conducted. A total of eight sandplay therapists stated their willingness to participate in the study, but one of them later indicated that they could not participate due to conflicts in the in-depth interview schedule. Pre-interviews were conducted to ensure an adequate understanding of the study, and the seven candidates who met the standards for participation were selected as the final participants.

Open-ended, in-depth interviews in qualitative studies generally involve a three-step consecutive structure, which includes a description of one's life, experiences related to the topic and the meaning of those experiences (Seidman, 1998). In this study, in-depth interviews were conducted across two to four sessions. The minimum was two sessions, and depending on the intensity of the interviews, more sessions were conducted. The sessions were scheduled about one week apart, and each session was conducted at a prearranged venue and time for about an hour or two. The venue was chosen to cater to each participant's convenience, ranging from 
the participants' consultation rooms to quiet locations near the researcher's office.

The participants received prior notice that the in-depth interviews will be recorded and used as research material. Apart from the recordings of the in-depth interviews, the study also referred to observation notes taken on each participant's overall attitude and behavior, the researcher's thoughts and a memo note with organized information for analysis.

The first session began with an open-ended question to each research participant asking about their co-transference experience. The door to the in-depth interview was opened by asking the participants to "describe the co-transference experience" that they have gone through. Follow-up sub-questions were then asked to gain a more specific view of the co-transference event, the emotions of the research participant and client, and the circumstances. The researcher refrained from asking restricted questions and followed along with the research participants' testimonies, trying to induce a specific illustration of their experience. At times, patience and silence helped the research participants recover their memories and shed light on aspects of the experience that have been overlooked (Van Manen, 1994).

The research participants described their current situation as a therapist, their life history and everyday life in any way they wished while focusing on the co-transference experience. The follow-up in-depth interview sessions after the first session involved descriptions of the meaning of the co-transference experience and consequent emotional changes, and how co-transference impacted overall treatment. When confirmation or supplementation of research material was needed after the in-person interviews, non-face-to-face reports were made through telephone calls, e-mails and text messages to obtain additional information for analysis.

\section{Data analysis}

Analysis of the materials gathered during the in-depth interviews of this research followed the four steps of analysis in Giorgi's descriptive phenomenology. In the first step, a reading was conducted of the entire recorded transcript along the entire context, followed by a more careful reading. Before the reading, time was spent listening to the recording of the in-depth interviews with a particular focus on the research participant's tone, voice or non-verbal expressions of emotion. Any part that was ambiguous in terms of the research participant's 
Journal of Symbols \& Sandplay Therapy, Vol.11 No.2.

description or emotional expression during the careful reading were reconfirmed through a repeated listening of the corresponding part.

The second step involved reading through the text and identifying the semantic units of the phenomenon. Approximately eight-hundred semantic units were identified based on the seven research participants' in-depth interviews on the co-transference experience.

In the third step, the derived semantic units were converted into explicit academic terminology. This may be the part in Giorgi's descriptive phenomenology that requires the most effort and care on the part of the researcher. Of the eight-hundred semantic units, any unit deemed repetitive or out of context was excluded, and only the final semantic units were used for analysis. The semantic units were converted into academic terminology and were re-grouped into common semantic units. During this step, the researcher proactively employed the technique of imaginative variation and remained focused on the nature of the phenomenon throughout the analysis.

In the final step, the experiences of the research participants were grouped based on the semantic units that have been converted into academic terminology. Through analysis and integration, three components and ten sub-components that constitute the nature of the co-transference experience were derived. The sub-components include forty-eight semantic units.

Giorgi(2004) stated that the third step is the most challenging step due to insufficient external standards that enable easier identification. The semantic units must be converted into clear and explicit forms in the psychological sense. The objective of the conversion is to identify the psychological meaning of the complex and specific experience as explicitly as possible. Structuralizing in the final step involves an examination of the psychological nature of the common experience. As such, the structure is not something that is universal, general or that can be categorized, but it represents the components or relationships that could include the definition of a phenomenon. When the central meaning is removed, the foundation of the structure will inevitably alter (Giorgi, 1997). 


\section{RESEARCH FINDINGS}

This section will discuss the results of the phenomenological qualitative study that analyzes the nature of the co-transference experience, based on the text of the in-depth interviews of the seven research participants.

Eight-hundred semantic units were identified by marking the parts in the research participants' testimonies where transitions of meaning occur. Of the identified semantic units, those that were repetitive or deviating from the context were excluded, leaving a total of 540 final semantic units that would be used for structural analysis.

The semantic units were grouped and compared, and the common factors were again summarized into 116 meanings. Based on these central meanings, three components and ten sub-components were structured.

The three components and ten sub-components that make up the structure of the nature of the co-transference experience were described based on the details of the in-depth interviews, and the ten sub-components include forty-eight semantic units. A general structure of the meaning of the nature of the co-transference experience will also be presented in this study.

\section{A. Components of the co-transference experience}

The components of the co-transference experience in sandplay therapy are listed in Table 2. The nature of the co-transference experience is made up of three components and ten sub-components. The ten sub-components include forty-eight semantic units. 
Journal of Symbols \& Sandplay Therapy, Vol.11 No.2.

Table 2. Components of the co-transference experience in sandplay therapy

\begin{tabular}{|c|c|c|}
\hline Component & Sub-component & Semantic Unit \\
\hline \multirow{15}{*}{$\begin{array}{l}\text { Meeting and } \\
\text { communication } \\
\text { between } \\
\text { two hearts }\end{array}$} & \multirow{5}{*}{$\begin{array}{l}\text { (1) Experiencing } \\
\text { the other } \\
\text { through } \\
\text { oneself }\end{array}$} & $\begin{array}{l}\text { I feel the desperate emotion of the client creating the sandpicture, through } \\
\text { the eye and hand motions }\end{array}$ \\
\hline & & $\begin{array}{l}\text { The relationship between the figure and the client reflects through me and } \\
\text { returns as an emotion }\end{array}$ \\
\hline & & $\begin{array}{l}\text { The image of the client interacting with sand brings a sense of silence and } \\
\text { peace }\end{array}$ \\
\hline & & The client's desire to be together invites me to the sandbox \\
\hline & & The emotions delivered by the figures are confirmed through me \\
\hline & \multirow{5}{*}{$\begin{array}{l}\text { (2) Experiencing } \\
\text { oneself } \\
\text { through the } \\
\text { other }\end{array}$} & $\begin{array}{l}\text { The mysteriousness of the sandbox makes me concentrate and become } \\
\text { immersed }\end{array}$ \\
\hline & & The struggle of the client makes my senses shiver \\
\hline & & My impatience is exposed through the figures \\
\hline & & Feeling the vague fear shared with the client, I switch to consciousness first \\
\hline & & The relationships outside the therapy room impact my view of the sandbox \\
\hline & \multirow{5}{*}{$\begin{array}{l}\text { (3) Mutual } \\
\text { feeling } \\
\text { between } \\
\text { oneself and } \\
\text { the other }\end{array}$} & $\begin{array}{l}\text { The boundaries dividing the client, sandbox and I disappear, and at that } \\
\text { moment, we are combined into one }\end{array}$ \\
\hline & & $\begin{array}{l}\text { Together we enter a vague and frightening space, like an empty box in } \\
\text { the middle of outer space }\end{array}$ \\
\hline & & $\begin{array}{l}\text { The client and I both express that we are together through the senses and } \\
\text { emotions }\end{array}$ \\
\hline & & $\begin{array}{l}\text { At one point, the sandbox, the client and I are connected, telling our } \\
\text { internal stories together }\end{array}$ \\
\hline & & $\begin{array}{l}\text { The mirror in the sandbox starts to reflect both the client's mind and my } \\
\text { mind }\end{array}$ \\
\hline \multirow{4}{*}{$\begin{array}{l}\text { Union in the } \\
\text { chaos of } \\
\text { memory }\end{array}$} & \multirow{4}{*}{$\begin{array}{l}\text { (1) Falling into } \\
\text { the chaos of } \\
\text { memory }\end{array}$} & $\begin{array}{l}\text { The sandbox awakens dormant memories, and conflict and confusion come } \\
\text { like an earthquake }\end{array}$ \\
\hline & & $\begin{array}{l}\text { The memory of the past that appears suddenly is vague, and the emotions } \\
\text { are still unclear }\end{array}$ \\
\hline & & The painful memory linked to the client makes my heart fluctuate \\
\hline & & $\begin{array}{l}\text { The invitation to the sandbox brings up the chaotic experiences of the past } \\
\text { into consciousness }\end{array}$ \\
\hline
\end{tabular}




\begin{tabular}{|c|c|c|}
\hline & \multirow{4}{*}{$\begin{array}{l}\text { (2) The scenes } \\
\text { from the past } \\
\text { replayed like } \\
\text { a dream }\end{array}$} & The pain of the memory summoned by the sandpicture is large and deep \\
\hline & & $\begin{array}{l}\text { The emotion triggered by the sandbox summons scenes from the past that } \\
\text { the body remembers }\end{array}$ \\
\hline & & Past memories come together with emotions and are replayed like a dream \\
\hline & & $\begin{array}{l}\text { The chaos of the sandpicture that invited me in reveals the chaos of } \\
\text { another memory }\end{array}$ \\
\hline & \multirow{5}{*}{$\begin{array}{l}\text { (3) Resistance } \\
\text { against a time } \\
\text { from beyond }\end{array}$} & $\begin{array}{l}\text { The figures that appear in the sandbox reflect my past, the one that I } \\
\text { have buried, covered and lived on as if it had never happened }\end{array}$ \\
\hline & & $\begin{array}{l}\text { The wariness of the client is linked to the fear of relationship and resists } \\
\text { the descent to the inner world }\end{array}$ \\
\hline & & To retain my competence, I choose the right role \\
\hline & & $\begin{array}{l}\text { I want to run away from the client's environment, which brings back } \\
\text { painful memories of the past }\end{array}$ \\
\hline & & $\begin{array}{l}\text { I struggle with my entire body so that the client does not notice my } \\
\text { discomfort with the relationship that has not been faced }\end{array}$ \\
\hline & \multirow{5}{*}{$\begin{array}{l}\text { (4) Finding 'us' } \\
\text { in the chaos } \\
\text { of time }\end{array}$} & $\begin{array}{l}\text { In the middle of chaos, the pasts are connected and at last, I come to } \\
\text { face the incident in my memory }\end{array}$ \\
\hline & & In the chaos of time, I, who am afraid, encounter the wary client \\
\hline & & $\begin{array}{l}\text { I withstand and endure the time of the vague past and come to a clear } \\
\text { vision of the scene from the past }\end{array}$ \\
\hline & & $\begin{array}{l}\text { As I stand in the middle of chaos and examine the scene from my } \\
\text { memory in the way it is, I come to an understanding of what it is trying } \\
\text { to say }\end{array}$ \\
\hline & & The image of myself in the memory resembles the client in the present \\
\hline \multirow{5}{*}{$\begin{array}{l}\text { Our wounds } \\
\text { awaken and } \\
\text { heal together }\end{array}$} & \multirow{5}{*}{$\begin{array}{l}\text { (1) The wounds } \\
\text { meet and } \\
\text { descend } \\
\text { together }\end{array}$} & $\begin{array}{l}\text { I face my wound through the wound of the client and find that the two } \\
\text { share a same root }\end{array}$ \\
\hline & & $\begin{array}{l}\text { The sad emotions of the client summon the unhappy child I was in the } \\
\text { past and make me cry }\end{array}$ \\
\hline & & $\begin{array}{l}\text { In the sandbox that I was invited into, I encounter my wounds, which are } \\
\text { not invited, and I step back }\end{array}$ \\
\hline & & $\begin{array}{l}\text { The client is in fear, not able to come closer, and I stand on the border, } \\
\text { looking at each other in pain }\end{array}$ \\
\hline & & $\begin{array}{l}\text { Descent to a painful place is frightening and hard, but with the } \\
\text { courageous client, I take a step forward }\end{array}$ \\
\hline
\end{tabular}




\begin{tabular}{|c|c|}
\hline \multirow{5}{*}{$\begin{array}{l}\text { (2) A mutual } \\
\text { recognition } \\
\text { and } \\
\text { understanding } \\
\text { of each other's } \\
\text { wounds }\end{array}$} & $\begin{array}{l}\text { By getting to know the wounded person in my memory, who is myself, I } \\
\text { now calmly face the wound of the client }\end{array}$ \\
\hline & $\begin{array}{l}\text { Knowing that the deficiencies of the client are my deficiencies, I no longer } \\
\text { try to patch up the wound }\end{array}$ \\
\hline & $\begin{array}{l}\text { I endure the painful time and come to listen to the stories delivered by } \\
\text { the figures in the sandbox }\end{array}$ \\
\hline & $\begin{array}{l}\text { The wound of the client and the wound of myself resemble each other like } \\
\text { a mirror, reflected in the way they are }\end{array}$ \\
\hline & $\begin{array}{l}\text { I recognize the anger in the relationship and no longer leave the client in } \\
\text { the fear of relationship }\end{array}$ \\
\hline \multirow{5}{*}{$\begin{array}{l}\text { (3) Awakening } \\
\text { of hope begins, } \\
\text { along with } \\
\text { healing }\end{array}$} & Waking from a long sleep, I meet a world I have never experienced before \\
\hline & $\begin{array}{l}\text { At the place where dark secrets disappear, anticipation and hope turn into } \\
\text { light }\end{array}$ \\
\hline & $\begin{array}{l}\text { Two air bubbles come together and become one big circle that contains } \\
\text { healing }\end{array}$ \\
\hline & $\begin{array}{l}\text { In the very place where wounds exist, day-to-day episodes began to } \\
\text { emerge, leading to a perception of the very place in this very moment }\end{array}$ \\
\hline & $\begin{array}{l}\text { Belief and patience melt the frozen psyche, and the hatching from the egg } \\
\text { begins }\end{array}$ \\
\hline
\end{tabular}

\section{Component 1. Meeting and communication between two hearts}

The things witnessed in sandpictures aroused certain feelings within each research participant, in this case, the sandplay therapist. The emotions of the research participant projected on the client, the emotions of the client projected on the research participant, and the emotions felt together by the two were combined into one mixture. This process did not occur consecutively. Instead, the emotions clashed and intertwined with one another at a certain point, expressed as a form of empathy. The deep level of empathy that emerged at the point of interaction prepared for a descent into the inner world and a convergence toward the unconscious. It was a moment of co-transference in which the two hearts meet, in which one experiences the other through oneself and experiences oneself through the other, going beyond transference or counter-transference. It is not yet clear what it is and what its nature is. It is the raw experience of something in its dormant form. 


\section{Component 2. Union in the chaos of memory}

The time of the client converged with the time of the research participant, or the therapist. At this point, the research participant encountered his or her oppressed memory. The event that the client is going through in the present was linked to the client's past, present and future, and this event converged with the past of the research participant and summoned scenes from another memory. The convergence of the therapeutic relationship between the client and therapist led to a vivid replay of oppressed memory in the chaos of time. The replay allowed the research participant to plainly perceive the past of the client and one's own past, the client's current situation and the event in one's memory. The memories of the therapist, who is resisting with the entire body, converged with the client and replayed like a dream. At last, the research participant was able to plainly accept the oppressed memory. Co-transference is the dramatic moment that comes after enduring a process of union in chaos and fighting against resistance.

\section{Component 3. Our wounds awaken and heal together}

The research participant relived the wounds of the past through the wounds of the client, accepted and went onto a path of healing. The painful wound of the past, as heavy as stone, was healed in the therapeutic relationship with the client, and the energy of the psyche started to flow again, which allowed the research participant to reunite with oneself in the present. The archetype of the wounded healer was recovered, and the oppressed emotions projected on the client were withdrawn. Together, they went forward into the light. The unconscious fear that had descended transformed into emotions such as hope, anticipation and excitement. An intersection of psychological descent and ascent occurred, and at this intersection, a moment of co-transference was encountered with light.

\section{B. General structure of the nature of the co-transference experience}

The general structure of an experience in a phenomenological study refers to the relationship between the topics of the experience. It involves an integration of analyses for each topic, based on the flow of time, flow of the inner world and the process of conscious 
Journal of Symbols \& Sandplay Therapy, Vol.11 No.2.

transformation (Giorgi, 1985). Through this process, all semantic units are integrated into a coherent structure, which may be described in general sentences.

\section{Component 1. Meeting and communication between two hearts}

The two hearts are invited to the sandplay therapy room, a place of freedom and protection. In this place, the two hearts communicate. This communication between the two hearts is the first component of the co-transference experience. Here, communication refers to 'moving together in contact with each other.' The research participants described how they experienced themselves and their clients. The emotional experience was, in fact, a description of the emotional relationship between oneself and the other, or the therapist and the client. The two hearts met, and one's heart moved together with the other's heart. It was a moment of communicative co-transference. As a component of co-transference, communication integrated the three sub-components and deepened.

The first sub-component, 'experiencing the other through oneself,' is a process of reporting the client's feelings with the therapist's feelings. The various feelings of the clients, including desperation, fear, longing and suspicion were revealed in the research therapists' testimonies. In the process of experiencing the client through oneself, a certain feeling of transference was involved.

The second sub-component is 'experiencing oneself through the other' in which the research participant expresses one's feelings through the client. The research participants discussed how they were so immersed in themselves that they would experience themselves before experiencing the client and how they went through eerie somatic responses from the client's transference. Sometimes, the minds of the research participants were too impatient and restless that they went ahead rather than follow.

In the in-depth interviews on co-transference, reports that felt like an expression of oneself and those that felt like an expression of the other were not ordered consecutively, but mixed. The two processes do not seem to have occurred consecutively, but it is clear that they were in contact with each other and moved together. Furthermore, the client was in contact with the emotions of 'oneself', and the therapist was in contact with the emotions of 'the other.' 
These semantic units came together and constituted the factors of communication.

The final sub-component, the 'mutual feeling between oneself and the other,' contains the essence of the co-transference experience. The two hearts met and started to move together. At times they moved along with each other, and sometimes one heart followed the other heart. The following are the research participants' descriptions of the moment of communication in which the emotions moved together and followed each other:

"At that moment, I really felt as if the client and I were a single being."

"The two of us were in an empty box floating in mid-air, and it was lonely and scary."

"At one point, the sandbox and the scene were connected and I experienced them together."

The two hearts experienced each other through communication, and at last, co-transference took place. Co-transference is a state of communication in which the two sides are in contact with each other and move and dance together. They withdraw their projections and engage in a true relationship and communication. The research participants' testimonies revealed that co-transference exist with projection, or transference, and that the boundary between transference and counter-transference is not clear. Neither territory can be kept at a distance through conscious judgment, nor psychologically manipulated. Throughout the process, the therapist and client engaged in a relationship of communicative co-transference.

\section{Component 2. Union in the chaos of memory}

The second component of co-transference is the union of memories from another time in the past. The memories of the client and the memories of the therapist come into a union; the present and the past come into a union; the consciousness and tacit memories come into a union. A union refers to the 'state of different things dissolving into one.' It is equivalent to Jung's terminology for archetypal transference, 'coniunctio.'

A union requires a bowl for dissolution. The research participant and client dived into the chaotic unconscious, where the union will take place. The past, present and future of the client 
Journal of Symbols \& Sandplay Therapy, Vol.11 No.2.

simultaneously met and mixed with the past, present and future of the therapist, and the therapist, or the research participant, encountered an oppressed memory from the past.

By definition, the union places its premise on the mixing of two different things, and when the two materials meet, chaos is inevitable. The first process of the union involved a chaos of memory, which the research participants portrayed as an 'earthquake,' 'conflict and confusion,' and 'vagueness.' The research participants often used expressions such as 'all of a sudden' or 'unexpectedly,' which suggests that the convergence of the present and the past was not a conscious or logical function but an unconscious phenomenon that appeared in a flash.

The research participant, fallen into the chaos of the past, summoned the oppressed memories. The past that they portrayed was as vivid as a dream from last night. "It seems that the body remembers." "Past experiences are coming back with memory." "Now that I look back at it, the wound is big and deep." The memories of the past have become distant from consciousness, but the body remembered them and were revived. Like a midsummer dream, the past was summoned, and the dream seemed to be originating from the client, not the research participant who experienced it. Where the research participant's oppressed memories were summoned and led to the dream, transference by the client also occurred. In the deepest area of the memory, the past of the client was also there. A research participant reported on a dream in the second in-depth interview session that included topics such as 'foggy scenery' and 'a bathtub with water flowing in and out.'

The oppressed memories triggered an emotional resistance from the research participants. The resistance felt like a physical struggle for survival. Saying things such as "I buried it and covered it, and lived on as if it never happened," "It will not be neglected," and "I do not want to show it," the research participants fought against it with their entire body. However, the co-transference union connected the past, present and future of the client and the therapist, and the connection through co-transference led the therapist to listen to the voices from inside. When the present of the client met the past of the therapist, the therapist resisted. However, the two different times came into a union, and liberation from the past occurred. The therapist's oppressed self in one's memory accepted the present self, and the therapist's past 
accepted the client's present.

\section{Component 3. Our wounds awaken and heal together}

The final component of co-transference is the healing of wounds. Healing literally means 'recovering from a disease.' It is the ultimate goal of psychotherapy. Psychotherapy is not about somatic diseases with tangible symptoms, but most clients who come to the place of consultation long for healing. Healing, which contains the nature of the co-transference experience, always involves a wound. The testimonies of the research participants indicated that the wounds of the therapist and client were in contact with each other and that at this place, healing occurred.

The first sub-component of healing begins when the wounds of the client and therapist meet with each other. The encounter foretells a deep descent. Just as there can be no rebirth without getting rid of the old and the ill, the descent foretells an awakening by healing. In the testimonies, the research participants began by talking about the client's wound and gradually moved on to reveal and accept their own wounds. As such, facing one's wound is always more difficult than facing another person's wound. Acceptance of the wound leads to emotional descent. Furthermore, sandpictures led the research participants to face complexes such as 'deficiency,' 'guilt,' 'suspicion,' and 'incompetence.' They went through their wounds once again through the client and were able to part with the old. As such, co-transference involves negative counter-transference emotions or complexes.

The descent of the two wounds portends the next step or the moment of awakening. It signals the coming of a reunion with a new life after healing the painful wounds of the past, which are heavy as stone. The research participants recovered the archetype of the wounded healer and retrieved the oppressed emotions projected on the client, and were no longer afraid to move forward toward the light. Describing the moment, the research participants said, "I felt as if the client was awakening," "There were things like anticipation and hope," "It was like breaking out of an egg." At last, feelings of hope, anticipation and excitement were aroused, foretelling re-birth.

The research participants awoke from the deep internal wounds and returned to reality. 
Journal of Symbols \& Sandplay Therapy, Vol.11 No.2.

The research participants, or the therapists, perceived the transference of the client through the unconscious and experienced the feeling of transference, albeit in a vague sense. The perception of transference led to a true understanding of the research participant and client through a new awakening. Back in the present, the research participants included a perception of oneself, as reflected in the client, in their testimonies. The research participants gained a new perception of oneself as the therapist and, at the same time, gained a new perception of the client. It is a reminder that co-transference is not unilateral. Transference and counter-transference continuously impact the therapeutic relationship, and the moment of co-transference can happen at any time or place.

Each of the components of co-transference - communication, union and healing - contain their own set of sub-components. The process is sometimes consecutive, and at times intermingled. However, regardless of the process, each of the sub-components organically interacts and breathes on its own, and only when they all exist together can co-transference function as a therapeutic relationship. The three components of co-transference themselves are also closely linked and at times share the sub-components.

\section{CONCLUSION}

Co-transference is a crucial element of the therapeutic relationship in sandplay therapy and is a concept that represents the unconscious bond between the client and therapist that occurs simultaneously and instantaneously. It also encompasses the concepts of consecutive transference and counter-transference. In general supervision or case meetings the focus is placed on analyzing transference with emphasis on the client's psychic dynamics to provide useful context for therapy. Therapists also perceive an immersion with their own emotional state as a phenomenon of negative counter-transference. Therefore, it is difficult to go into depth on emotional transference. The therapist's particular feelings or a strong feeling of transference in a therapeutic relationship are not sufficiently explored.

This study aims to explore and structuralize the co-transference experience created by a 
sandplay therapist and the client in the field of consultation, thereby identifying the meaning of the nature of the experience.

This study takes a phenomenological and qualitative approach and seeks to trace the direction taken by the sandplay therapist's consciousness in a co-transference experience to understand the nature of this pure and fundamental experience. It adopts Giorgi's phenomenological study method, which focuses on describing the meaning and nature of an experience, among other qualitative research methods.

The meaning of the nature of the co-transference experience in sandplay therapy was identified by studying the cases of seven sandplay therapists. The nature of the co-transference experience was analyzed based on the text of in-depth interviews of the research participants. By marking the parts in the research participants' testimonies where a transition of meaning occurred, eight-hundred semantic units were identified. Of the identified semantic units, those that were repetitive or deviating from context were excluded, leaving 540 final semantic units that would be used for the structural analysis. The semantic units were grouped and compared, and the common factors were again summarized into 116 meanings. Based on these central meanings, three components and ten sub-components were structured. The ten sub-components include forty-eight semantic units.

The three components make up the nature of the co-transference experience. In the first component, "meeting and communication between the two hearts," the hearts of the client and therapist came into contact with each other and moved together. It was a moment of emotional empathy and communication. The research participants described the deep empathy between the therapist and client as a meaning of the nature of co-transference. In the second component, "union in the chaos of memory," the past and present of the research participant and the past and present of the client were intertwined and converged into past memory. The research participants revealed that the union with the client that entailed chaos was an important meaning of co-transference. It was a convergence of time, and the memory played out based on the union. The union of memory allowed the research participant to take a journey to the past, and a large part of the testimony was allocated to the research participant's own past. In the third component, "our wounds awaken and heal together," the research participant started with the chief complaint, or wound, of the client, but later came to 
Journal of Symbols \& Sandplay Therapy, Vol.11 No.2.

face one's own wound that was linked to the client. At the place where the wounds met, the archetypal energy of healing was aligned.

Co-transference may also be understood as a general combined structure of communication, union and healing. The in-depth interviews on co-transference with the research participants transcended time and space. The sandpictures and clients were placed at the center of the testimonies. Through co-transference, the research participants communicated with the clients, came into a union with the sandbox and went on to a road of healing through their wounds.

At times, the sandplay therapists felt a holy sense of awe in their encounters with the clients who created the sandpictures, and at other times they experienced deep empathy for the inner pain that could not be expressed in words. Sometimes, they were infected by the transference of the client and fell into a state of unconscious confusion. Throughout the in-depth interviews, the sandplay therapists gave their vivid accounts of how co-transference, an archetypal union and valuable integration, led to changes in the therapeutic relationship and enabled healing.

Based on the research participants' descriptions, the components of co-transference were not a set of different events but entailed continuity. Rather than treating them like separated parts of co-transference, it would be more proper to understand them as a simultaneous process. As they described their co-transference experience in the in-depth interviews, the research participants readily accepted the invitation to their past or the unconscious, apart from the treatment setting. This study demonstrates, through the components of the experience, that this linkage to the inner world of the research participant is a prerequisite for co-transference.

The co-transference experience involves the therapist and client encountering each other and coming into an unconscious relationship, waking up from that dream-like encounter and returning to the present self. The therapist gains a new perception of oneself, comes to truly love and gain a deeper understanding of the client, and is liberated from sympathy. The co-transference experienced by the research participants is an interaction with the client in which the two communicate with each other through the mobilization of unconscious memories, senses and emotions, moving away from the interpretation of transference.

This study finds its significance in providing sandplay therapists an opportunity to gain insight into the strong therapeutic moment of co-transference and what kind of event it is, 
going beyond an extension of psychotherapy. Furthermore, it seeks to give sandplay therapists an opportunity for introspection as a psychological container before the sandbox in a sandplay therapy room: a space of temenos.

\section{References}

Bradway, K. (1991). Transference and countertransference in sandplay therapy. Journal of sandplay therapy, 1(1).

Bradway, K., \& McCoard, B. (1997). Sandplay-silent workshop of the psyche. London: Routledge.

Choi, M-S. (2005). A study for the development and countertransference utilization inventory. ( Unpublished Doctoral dissertation). Yonsei University, Seoul, Korea.

Choi, M-S., \& Lee, Y-A. (2009). Relationships among the self-efficacy, social support and the countertransference management ability of the playtherapist. Korean Journal of Play Therapy, 12(3), 31-45.

Giorgi. A. (1985). Phenomenological and psychological research. Pittsburgh, PA: Duquesne University Press.

Giorgi, A. (1997). The theory, practice, and evaluation of the phenomenology methods a qualitative research. Journal of Phenomenology, 28, 235-260.

Giorgi, A. (2004). Qualitative research methodology: Advanced workshop on the descriptive phenomenological method. Advanced Workshop on the Descriptive Phenomenological Method, 2-55.

Jacoby, M. (1990). Individuation and narcissism: The psychology of self in Jung and Kohut. London/New York: Routlege.

Jang, M-K. (2017). Analytical phychologican sandplay therapy. Seoul: Hakjisa.

Jung, C. G. (1966). Psychology of the transference. Princeton, NJ: Princeton University Press.

Jung, C. G. (1966/1993). Principles of practical psychotherapy. In C. G. Jung, The Practice of psychotherapy (2nd ed.). East Susses: Routledge.

Kalff, D. (1980). Sandplay: A psychotherapeutic approach to the psyche. Cloverdale, CA: Temenos Press. Kim, B-H., Kim, K-J., Lee, K-J., Kim, J-K., Hong, J-J., Lee, M-W., Kim, Y-H., Yoo, I-Y., \& Lee, H-Y. (1999). A comparison of phenomenological research methodology. Journal of Korean Academy of Nursing, 296), 1208-1220.

Kim, H-J., \& Kim, K-W. (2007). The effects of the ego-resiliency, stress coping style and 
Journal of Symbols \& Sandplay Therapy, Vol.11 No.2.

countertransference management ability of playtherapists. Korean Journal of Play Therapy, 101), $35-46$.

Kim, J-H., \& Ahn, H-N. (2013). The relationship among counselors' level of development, mindfulness and countertransference management. Journal of Human Understanding, 34(2), 95-109.

Lee, M-W. (2007). Phenomenology as a qualitative research methodology : A mode of dialectic study between uniqueness and universality of the phenomenon. Journal of Anthropology of Education, 1Q2), 41-64.

Lee, Y-S. (2010). The effects of novice counselor's difficulty, countertransference management ability on the counseling outcome. Korean Journal of Counseling, 11(3), 1021-1035.

Lim, K-W., \& Kim, J-H. (2008). The effects of counselor development level and countertransference utilization ability on counseling outcome. Korean Journal of Counseling, 933), 987-1006.

Montecchi, F. (1991). Hands that talk and analytical listening. Journal of Sandplay Therapy, $8(1)$, $25-67$.

Moustakas, C. (1994). Phenomenological research method. Thousand Oaks, CA: Sage Publications.

Schore, A. N. (2003). Affect regulation and disorder of the self. New York: W. W. Norton \& Co., Inc.

Schore, A. N. (2012). The science of the art of psychotherapy. New York: W. W. Norton \& Co., Inc. Seidman, I. (1998). Interviewing as qualitative research. NY: Teachers College Press.

Stern, D. (2008). The clinical relevance of infancy: A progress report. Infant Mental Health, 29(3), 177-188.

Stewart, L. H., \& Chodorow, J. (2000). Sandplay and active imagination. The San Francisco Jung Institute Library Journal, 18(3), 41-49.

Tesch, R. (1990). Qualitative research: Analysis types and software tools. New York: Falmer Press. 
상징과모래놀이치료, 제 11 권 제 2 호

Journal of Symbols \& Sandplay Therapy

2020, 12, Vol. 11, No. 2, 167-184.

doi https://doi.org/10.12964/jsst.20009

\title{
모래놀이치료에서 \\ 치료자의 공동전이 경험에 대한 현상학적 연구*
}

A Phenomenological Study of the

Therapists' Co-transference Experiences in Sandplay Therapy

\author{
권 미 라**
}

Kowen, Mee Ra

\begin{abstract}
$<$ Abstract $>$
In this study, we examined the co-transference experiences of sandplay therapists. We applied the descriptive phenomenological method developed by Amedeo Giorgi. To begin with, we interviewed seven therapists and analyzed the data. Of the 800 semantic units identified, we used 540 of them, excluding the repetitive, or those deviating from context. By comparing these items, we identified 116 meanings. We structured three components and 10 sub-components based on the central meanings. The components comprised the co-transference experience, while the sub-components contained 48 semantic units. In our interviews, we noted that the participants were placing their clients' sand scenes in the center of their statements. Thus, the pairs had fused with the sand trays and healed each other's wounds. The total structure of empathy and healing made up co-transference.
\end{abstract}

Keywords : sandplay therapy, sandplay therapist, co-transference, transference, archetype

* 본 논문은 남서울대학교 박사학위 논문을 수정 - 보완한 논문임.

** 리본심리상담센터, kowen0808@naver.com 
Journal of Symbols \& Sandplay Therapy, Vol.11 No.2.

\section{I. 서 론}

\section{1. 연구의 목적 및 필요성}

모래놀이치료는 언어의 합리성을 잠시 떠나 말없음의 길을 따라 자신을 표현하는 방법, 즉 의식의 마음을 잠잠하게 함으로써 무의식에게 표현할 수 있는 기회를 주어 치유와 변화 를 일으키는 심층심리치료이다(Steninhard, 2013). 내담자가 모래장면을 창조할 때 치료자는 이 창조의 세계에 출현하는 상징들을 목격하게 된다. 이러한 모래놀이치료 장면에서 일어 나는 내담자와 치료자 사이의 치료적 관계, 즉 공동전이(co-transference)의 경험은 상징의 의 미를 조율하고 이는 치유로 연결된다(장미경, 2017).

분석심리학적 입장을 기본으로 두는 심리 치료는 치료자와 내담자 간의 관계의 장(field), 상호작용의 장(Jacoby, 1990), 상호주관적 장(Stolorow \& Atwood, 1992)에서의 역동적 상호작용 을 포함하고 있다. Jung(1966)은 전이심리학에서 치료적 2인 관계를 연금술의 용기(容器)안 에서 상호작용하는 치료자와 내담자의 의식과 무의식의 상호 작용으로 기술한다. 이러한 견해는 심리치료의 상호작용을 전이와 역전이의 무의식적이고 원형적인 관계의 상호작 용이라는 더 크고 복잡한 개념으로 확충시킨다(Friedman \& Michell, 2007). 이것은 전이 (transference)와 역전이(counter-transference)를 공동전이(co-transference)의 개념으로 포괄한 것 이다.

모래놀이치료에서의 치료적 관계는 치료자와 내담자 간의 투사(projection)와 관련된다. 내 담자의 치료자에 대한 투사는 내담자의 과거나 현재에 기인한 감정의 전이뿐만 아니라 치 료자의 과거 그리고 현재의 경험과 함께 작용한다는 점에서 공동전이는 반하는(counter) 감 정이라기보다 함께 함(co)의 감정을 포괄하는 치료적 감정 관계이다(Bradway, 1991). 내담자 가 창조한 모래상자에 내면의 무의식이 활성화되면 치료자와 내담자는 직관적인 연결을 맺 고 이 때 깊은 인식과 비언어적 깨달음의 순간을 맞이한다(Kalff, 1980). Kalff는 공동전이 (co-transference)라는 용어 출현 이전에 '동시성의 순간(synchronistic moment)'이라는 용어로 전 이 상황을 기술하였으며 모래놀이치료에서의 “궁극적인 치료의 순간(ultimate therapeutic moment)"이라고 하였다(Bradway \& McCoard, 1997). 이때 내담자와 치료자 간의 깊은 무의식 적 유대가 내담자의 내적 변환으로 나타난다(Montecchi, 1991). 전이, 역전이가 순차적인 개 념을 강조하였다면 공동전이는 내담자와 치료자 간에 동시적이고 순간적으로 일어나는 무 의식적 유대의 개념이다. 공동전이는 정신의 억압된 측면이나 개인의 기억이 원형(archetype) 의 상징으로 출현한 이미지를 동반한다(Montecchi, 1991).

현대 심리치료의 새로운 패러다임의 변화는 의식 즉 좌뇌 중심의 접근에서 무의식 즉 우 뇌 중심의 접근으로 향하고 있다(Schore, 2003). 이는 인지적 접근에서 정서적 접근으로의 변 
화를 담고 있으며 내담자의 과거 외상 경험이 치료자에 의해서 동시적으로 경험되는 치료 관계의 정서적 혼합인 공동전이의 중요성을 강조한 것이라 하겠다(Schore, 2012). 치료자가 갖는 무의식에 대한 깊은 이해와 우뇌의 정서적 민감성은 진정한 치료의 도구로써 내담자 와 치료자의 관계 그 안에서 작용한다(Stern, 2008). 모래놀이치료자는 치료적 관계 안에서 공동전이의 경험을 통해 내담자의 정서 상태를 경청한다.

앞서 언급한 바와 같이 공동전이(co-transference)는 모래놀이치료의 치료적 관계 형성의 필 수 요소이다. 그러나 일반적인 수퍼비젼이나 사례회의에서는 내담자의 정신 역동을 중심에 두고 해석하고 분석하여 치료에 유용한 맥락을 제공하는 것에 초점을 두어 치료자의 특별 한 감정 또는 강렬한 전이감을 충분히 다루지 못한다. 치료자 역시 자신의 감정 상태에 몰 입하는 것을 부정적 역전이 현상으로 인식하여 전이 감정을 깊이 다루기가 쉽지 않다. 이 러한 점에서 연구자는 모래놀이치료자를 연구 참여자로 두고 심층면담을 통해 공동전이 경 험의 본질적 의미에 다가가고자 한다.

치료적 관계를 다룬 국내 선행연구들은 주로 상담자의 역전이 경험에 대한 접근이었으며 역전이 경험을 탐색하여 이를 치료의 유용함으로 연결하려는 연구 경향이 두드러진다(최명 식. 2005; 임고운 \& 김지현, 2008; 황인호, 2005; 이영순, 2010; 김현주 \& 김광웅, 2007; 김준 혜 \& 안현의. 2013; 최지영 \& 이영애, 2009). 또한 공동전이의 치료적 관계에 대한 국내 선 행 연구는 찾아볼 수 없다. 본 연구를 통해 공동전이의 연구 주제가 모래놀이치료 영역에 서 다루어진다면 치료적 관계인 전이에 대한 폭넓은 논의가 가능할 것으로 여겨진다.

모래놀이치료는 모래상자와 치료의 과정에 대한 심층적인 분석을 통해 내담자의 전언어 적 트라우마와 관련된 정서를 상징적으로 이해하고 무의식, 원형 등의 의식 저 너머 세계 를 치료의 중요한 영역으로 다룬다(Turner, 2004). 무의식의 영역과 관련된 치료적 관계인 공동전이의 본질적 의미는 경험의 당사자인 치료자의 생생한 목소리를 통해 현상에 다가갈 필요가 있으므로 현상학적 접근이 타당할 것으로 판단된다.

Giorgi의 현상학적 경험 연구의 방법을 통해 양적 연구나 정신물리학적인 접근의 한계를 넘어 모래놀이치료자가 경험하는 공동전이(co-transference)의 구체적인 경험의 본질을 파악함 에 본 연구의 목적을 둔다(Giorgi, 1985). 공동전이는 치료적 관계에서 상호 소통하고 변화하 는 직접적이고 살아 숨 쉬는 현상으로 개념적으로 또는 인과론적인 자연과학적 접근으로는 본질에 다가 갈 수 없다. 기술적 현상학 연구는 심리 현상을 물리적 대상으로 보지 않고 그 어떤 전제나 조작 없이 경험하는 대상이 생생하게 경험하는 그대로의 본질적 의미를 탐 구한다(Giorgi, 1985). 심리 현상을 양적이고 과학적인 태도의 그늘로부터 벗어나게 하여 자 연적 태도, 즉 현상학적인 태도로 탐구하는 것이 본 연구의 지향점이다.

의식과 무의식이 조우하는 모래놀이치료에서 내담자와 치료자의 우뇌와 우뇌의 소통 (Schore, 2003), 무의식과 무의식의 연결(Jung, 1966)인 공동전이의 현상은 치료적 관계 형성 
Journal of Symbols \& Sandplay Therapy, Vol.11 No.2.

의 중요한 요소이며 심층 심리치료의 결과에 지대한 영향을 미친다(Bradway, 1991). 모래놀 이치료자가 모래 상자를 창조하는 내담자와 만나면서 경외감을 느끼기도 하고, 말이 전해 주지 못하는 내면의 고통을 깊이 공감하기도 하며 내담자의 전이에 감염되어 무의식적 혼 란 상태에 빠지기도 한다. 원형적 융합이자 가치로운 혼합인 공동전이가 치료적 관계의 변 화를 가져오고 치유로 연결됨을 모래놀이치료자는 공동 전이의 경험으로 알고 있다. 그러 나 심리적인 현상인 이 모호한 사태의 본질은 일반화하여 파악하기 어려우며 그 현상의 본 질적 의미에 대한 의구심은 여전히 존재한다.

이에 본 연구는 모래놀이치료자의 공동전이(co-transference) 경험을 치료자 의식의 지향성 을 추적하여 그 현상에 대한 순수 경험, 본질적인 경험의 본질을 현상학적 질적 연구 방법 으로 접근하고자 한다. 연구 수행을 위해서 실증주의적인 관점이 아닌 현상의 본질을 구체 적으로 드러나게 하는 질적 연구 방법 중 특히 경험의 의미와 본질을 기술하는데 초점을 둔 Giorgi의 현상학적 연구 방법을 사용하였다. 이를 통해 모래놀이치료자가 상담의 장(field) 에서 내담자와의 함께 창조하는 공동전이 경험을 탐색하고 구조화하여 그 경험의 본질적 의미가 무엇인가를 알고자함이 본 연구의 목적이다.

\section{2. 연구문제}

본 연구는 모래놀이치료자의 모래놀이치료 장면에서 경험하는 공동전이(co-transference) 경 험의 본질에 대한 의미를 Giorgi의 기술적 현상학 연구 방법을 적용하여 살펴보고자 한다. 현상학적 연구를 통해 연구 참여자들의 경험에 대해 좀 더 실제적이고 총체적으로 접근하 여 현상에 대한 본질적인 이해를 본 연구의 목적으로 두고 있다.

본 연구 목적을 달성하기 위해 다루고자하는 연구 문제는 다음과 같다.

1) 모래놀이치료에서 공동전이는 치료자에게 어떠한 경험인가?

2) 모래놀이치료자의 공동전이 경험의 본질적 의미는 무엇인가?

\section{ㅍ. 연구방법}

\section{1. 현상학적 연구방법}

본 연구는 질적 연구 방법 중 특히 경험의 의미와 본질을 기술하는데 초점을 둔 Giorgi의 현상학적 연구 방법을 사용하였다. Giorgi는 Husserl의 현상학을 계승하여 심리학적 현상학을 사회과학의 질적 연구방법으로 정립한 미국의 심리학자이다(Tesch, 1990). Giorgi는 원래 양 
적연구방법을 토대로 한 정신물리학 전문가였으나, 양적연구방법 및 정신물리학의 한계를 깨닫고 현상학적 경험연구 방법을 개발하면서 현상학적 심리학을 개척하였다(Giorgi, 1985). 그는 철학으로서의 현상학적 탐구대상의 본질은 “보편적인” 반면 인문과학으로서의 현상학 적 심리학의 탐구대상으로 삼는 본질은 “보편적이라기보다는 유형적이고 일반적이다”라고 하였다(Giorgi, 1985. p. 78).

현상학은 다양한 질적 연구방법론으로 분화하는데 대표적으로 Giorgi의 기술적 현상학, van Manen의 해석학적 현상학으로 대별된다(이근호, 2007). 해석학적 현상학이 현상이 포함 하고 있는 반성적이고 실존적인 차원을 드러내는데 관심을 기울이는데 반해, Giorgi는 의 식 속에서 드러나는 것으로써 현상의 본질을 기술하는 일에 초점을 맞추는 기술적 현상학 (descriptive phenomenology)을 발전시켰다.

인간은 자신의 경험을 주관적으로 해석하고 의미를 부여하기 때문에 개별적이고 사례 중 심적(idiographic)인 기술(description)을 통해 경험은 새롭게 이해되는 것이다(김분한 외, 1999). 이러한 인식론적, 존재론적 관점은 주체와 객체, 관찰자와 연구대상, 인간과 사회를 이분법 적으로 보지 않고 생활세계 속에서 상호작용하면서 자신의 경험을 이해하고 새롭게 구성해 가는 인간의 주체적이고, 총체적인 측면을 강조한다. 특히 인간의 경험에 관한 연구에서 현 상학 연구자들은 지각과 판단의 모든 복합성을 가진 인간에 의해 경험되는 현상을 연구함 으로써 경험의 개인적 의미를 파악하는 기술(description)을 통해 연구대상의 실재에서 그들 을 파악하고 도울 수 있다고 한다(김분한 외, 1999).

현상학적 연구는 다른 사람으로부터의 경험을 기술하는 데서 시작된다. Giorgi는 인간현 상을 이해하는데 가장 중요한 것은 기술(description)이라고 보았으며, 해석(interpretation)은 2 차적인 것으로써 본질을 이해하기 위해서는 연구자가 연구 참여자의 언어로 드러낸 내용을 단순히 기술하는 것이 아니고, 환원시켜 연구 목적에 부합되도록 하는 해석이 요구되는데, 기술의 한 형태로 보았다. 즉, 해석 이전에 바로 거기에 있는 것을 먼저 보자는 입장을 취 하고 있다(Giorgi, 1985). 기술은 협소한 분석단위인 중요한 진술로부터 더 넓은 분석단위인 의미단위까지 그리고 연구 참여자들이 무엇을 경험 했는지, 그것을 어떻게 경험했는지를 요약한 상세한 기술에 이르기까지 진행되는 체계적인 절차를 따르는 자료 분석을 통해 이 루어진다(Moustakas, 1994).

본 연구자는 Giorgi의 현상학적 경험 연구의 특성에 따라 연구대상의 관찰과 이해를 위해 대상이 되는 그 환경에 직접 들어가고(김윤옥 외, 1996), 그 환경 안에서 자료를 수 집하여, 이런 이야기들을 축적함으로써 모래놀이치료 상담 장면에서 펼쳐지는 공동전이 (co-transference) 가 어떤 경험이며 그것이 연구 참여자인 모래놀이치료자에게 어떻게 경험되 는가에 관해 집중하고자 한다.

본 연구에서 탐색하고자 하는 모래놀이치료자의 공동전이 경험은 개별적이고 주관적인 
Journal of Symbols \& Sandplay Therapy, Vol.11 No.2.

것을 특징으로 하는 현상이며, 실존적 현상에서 말하는 개별자로서의 인간의 성격을 나타 내므로 과학적인 수량화로 나타내는 양적인 연구로는 한계가 있으므로 공동전이 경험을 기 술하고 본질적인 구조를 조망하는 데에 현상학적 질적 연구 방법을 적용한다.

2. 연구 참여자

\section{1) 연구 참여자 선정 절차}

질적 연구 표본선정의 원칙과 절차에 따라 30-60대의 모래놀이치료자 7명을 연구 참 여자로 선정하였다. 선정된 연구 참여자들은 주제에 대한 깊이 있는 심층적 경험 기술 (description)이 가능하였으며 또한 연구 참여자들은 진솔하고 적극적인 자세는 경험담의 진 술을 풍부하게 하는 또 다른 조건이 되었다.

\section{2) 연구 참여자 특성}

연구 참여자 7명에 대한 일반적 특성은 표 1과 같다.

표 1. 연구 참여자의 일반적 특성

\begin{tabular}{cccc}
\hline 구분 & 성별 / 나이 & 상담 경력 & 최종 학력 / 전공 \\
\hline 참여자 1 & 여 / 만 64세 & 14년 & 석사수료/심리상담 \\
\hline 참여자 2 & 여 / 만38세 & 12년 & 석사졸업/가족상담 \\
\hline 참여자 3 & 여 / 만 39세 & 7년 & 석사졸업/상담심리 \\
\hline 참여자 4 & 여 / 만 56세 & 15년 & 석사졸업/상담심리 \\
\hline 참여자 5 & 여 / 만 30세 & 6년 & 석사/졸업아동상담 심리치료 \\
\hline 참여자 6 & 여 / 만 39세 & 15년 & 석사졸업/아동상담 심리치료 \\
\hline 참여자 7 & 여 / 만 36세 & 13년 & 석사졸업/아동상담 심리치료 \\
\hline
\end{tabular}

\section{3. 자료 수집 및 분석}

\section{1) 자료수집 방법과 절차}

연구의 충분성을 위해 본 연구의 연구 참여자의 사례 수에는 제한을 두지 않고 연구 참 여자 모집을 실시하였으며 최종적으로 7 명의 사례를 통해 모래놀이치료에서의 공동전이 (co-transference) 경험의 본질적 의미를 도출하였다.

2018년 10월부터 11월까지 연구 참여자 모집 기간을 가지고 2018년 11월부터 2019년 7월 
까지 심층면담이 진행되었다. 연구 참여 의사를 표현한 모래놀이치료자는 총 8 명이었으며 그 중 1 명은 심층면담 일정이 맞지 않아 연구에 불참석 의사를 밝혔다. 참여자들과의 사전 예비 면담을 통해 연구에 대한 충분한 이해의 시간을 가지고 연구 참여자 선정 기준에 부 합하는 7명을 최종 연구 참여자로 선정하였다.

질적 연구의 개방형 심층면담은 통상적으로 자신의 생애, 주제와 관련된 경험, 경험에 대 한 의미로 구성되는 3단계의 연속적 구조로 이루어진다(Seidman, 1998). 본 연구의 심층면담 은 2회에서 4회로 진행되었으며 최소한 2회 상담을 기본으로 정하고 심층면담의 포화도에 따라서 회기를 연장해서 진행하기도 하였다. 회기와 회기 간에는 일주일정도의 시간의 경 과를 두었으며 미리 약속된 시간과 장소에서 1 시간에서 2 시간 정도 실시하였다. 심층면담 의 장소는 연구 참여자의 편의를 고려하여 연구 참여자의 상담실 또는 주변의 조용한 곳과 연구자의 연구실 등으로 다양화 하였다.

심층면담 내용은 녹음될 것이며 연구 자료로 사용될 예정임을 미리 고지하였다. 심층면 담 녹취 자료 외에 연구 참여자의 전반적인 태도와 행동을 관찰한 관찰 일지와 연구자의 단상과 분석에 필요한 자료를 정리한 메모 노트도 연구에 활용되었다.

첫 회기는 연구 참여자에게 공동전이의 현상은 어떤 경험인지를 묻는 개방형 질문으로부 터 시작되었다. “당신의 공동전이 경험에 대해서 말씀해주세요."라는 큰 질문으로 심층면담 의 문을 열고 공동전이의 상황이나, 연구 참여자와 내담자의 정서, 상황을 구체화 할 수 있 는 보충 질문 등이 하위 질문으로 심층면담이 진행되었다. 그 외의 제한적인 질문은 되도 록 지양하고 연구 참여자의 진술을 따라가며 그들의 경험을 구체적인 수준으로 드러내도록 노력하였다. 때로는 인내나 침묵이 연구 참여자의 기억을 되살리고 경험에 대해서 간과하 고 있던 부분을 일깨우기도 하였다(Van Manen, 1994).

연구 참여자의 공동전이 경험을 중심으로 하여 연구 참여자의 치료자로서의 현재 상황, 생애사와 생활 세계에 대한 기술 등이 자유롭게 이루어졌다. 첫 회기 이후의 심층면담은 공동전이 경험의 의미와 그로인한 감정의 변화, 전반적인 치료 회기에 공동전이가 미치는 영향 등이 다양하게 진술되었다. 대면 심층면담이 이루어진 후에도 자료의 확인과 보완이 필요한 경우에는 전화면담과 전자 메일, 휴대 전화 문자 수신을 통한 비대면 보고를 통해 자료 분석의 보충 자료를 확보하였다.

\section{2) 자료 분석}

본 연구의 심층면담을 바탕으로 한 자료 분석은 Giorgi의 기술적 현상학의 4단계의 분석 절차를 따라 수행하였다. 1 단계의 기술내용 읽기는 전체적 맥락을 따라 녹취록을 통독하고 다시 정독하는 방법을 반복하였으며, 읽기 전에는 심층면담의 녹음 내용을 연구 참여자의 음성의 톤, 음조 또는 비언어적인 정서의 표현 등과 함께 경청하는 것에 시간을 할애하였 
Journal of Symbols \& Sandplay Therapy, Vol.11 No.2.

다. 정독 중에도 진술내용이나 정서적 표현이 애매한 부분은 재 청취를 통해 연구 참여자 의 진술 내용을 확인하였다.

2단계에서는 텍스트의 내용을 읽으면서 현상 자체의 의미단위를 구분하는 작업을 수행하 였다. 7 명의 연구 참여자들의 공동전이 체험의 심층면담 내용을 바탕으로 800 여개의 의미 단위를 도출하였다.

3단계는 도출된 의미 단위를 학술적 용어로 명시화하는 작업으로 Giorgi의 기술적 현상학 에서 연구자의 노력과 고심이 가장 필요한 부분이라 하겠다. 800 개의 의미단위 중 반복되 는 구절이나 맥락에서 벗어났다고 여겨지는 의미 단위들을 제외하고 최종 도출된 의미단위 가 분석에 사용되었다. 의미 단위는 학문적 용어로 변형되었으며 연구 참여자들의 공통 의 미단위로 재통합되었다. 이 단계에서 연구자는 자유 변경법을 적극 사용하고 현상학적 환 원의 자세를 분석하는 동안에 견지하였다.

마지막으로 학문적 용어로 전환된 의미단위를 기초로 하여 연구 참여자의 경험을 통합하 는 작업을 수행하였다. 이러한 분석과 통합의 과정을 거쳐 공동전이 경험의 본질을 형성하 는 3 개의 구성요소는 10 개의 하위구성요소들을 도출하였다. 하위구성요소는 48 개의 의미단 위를 포함하고 있다.

Giorgi(2004)는 특히 3단계가 쉽게 식별할 수 있는 외적 기준이 부족하기 때문에 가장 어 려운 단계라고 한다. 의미단위가 심리학적으로 명시적 형태로 분명하게 되도록 해야 한다 는 뜻이다. 전환의 목적은 복합적이고 구체적인 경험들의 심리학적 의미를 가능한 한 분명 하게 만드는 데 있다. 마지막 단계로 구조는 무엇이 같은 유형의 일련의 경험에 대한 심리 학적인 본질인가를 살펴보는 것이다. 즉 구조는 보편적이거나, 일반적 혹은 유형화될 수 있 는 종류의 것이 아니라, 현상에 대한 정의가 포함될 수 있는 구성요소들이나 관계들을 의 미한다. 구조는 만일 중심의미가 제거되면 근본적으로 변화할 수밖에 없다는 기준을 갖는 다(Giorgi, 1997).

\section{III. 연구결과}

본 장에서는 7명의 연구 참여자의 심층면담 텍스트를 기반으로 그들의 공동전이(co-transference) 경험의 본질을 현상학적 질적 연구 방법으로 분석한 결과를 소개한다.

연구 참여자들의 진술 중에 의미의 전환이 이루어지는 부분을 표시하여 800 여개의 의미 단위를 도출하여 그 중에 반복되거나 맥락에서 벗어난 의미단위를 제외한 540 개의 의미단 위를 최종 구조 분석의 의미 단위로 사용하였다. 연구 참여자들의 의미단위를 통합하고 비 교하여 공통의 요소를 다시 116 여개로 의미로 요약하였다. 이렇게 도출된 중심의미를 바탕 
으로 3 개의 구성요소와 10 개의 하위구성요소를 구조화하였다.

공동전이 경험의 본질 구조를 구성하는 3 개의 구성요소와 10 개의 하위구성요소를 심층면 담 내용에 기반하여 기술하였으며 10 개의 하위구성요소는 48 개의 의미 단위를 포함하고 있 다. 이와 더불어 공동전이 경험의 본질적 의미의 일반적 구조를 제시하고자 한다.

\section{1. 공동전이 경험의 구성요소}

모래놀이치료자의 공동전이(co-transference)의 경험의 구성요소는 표 2와 같다. 공동전이 경 험의 본질은 3 개의 구성요소와 10 개의 하위 구성요소로 이루어졌다. 10 개의 하위 구성요소 는 48 개의 의미 단위를 포함하고 있다.

\section{1) 구성요소 1. 마음과 마음이 만나 교감하다}

모래장면에서 목격한 것은 치료자인 연구 참여자의 감정을 불러일으켰다. 내담자에게 투 사된 연구 참여자의 정서와 연구 참여자에게 투사된 내담자의 정서, 함께 느끼는 정서가 혼재되어있다. 순차적인 과정이라기보다는 각각의 정서가 어느 순간 부딪히고 혼합되어 공 감의 형태로 표현되었다. 교감하는 지점에서 출현한 깊은 공감은 내면세계로의 하강, 무의 식으로의 융합을 준비한다. 나를 통해 너를 느끼고 너를 통해 나를 느끼는 전이, 역전이를 넘어 교감하는 공동전이의 순간을 맞이한다. 아직은 실체가 무엇인지, 본질은 무엇인지 알 수 없는 잠재적인 그대로의 상태, 순수 경험으로 만난다.

\section{2) 구성요소 2. 기억의 혼돈 속에서 우리는 융합하다}

내담자의 시간과 연구 참여자인 치료자의 시간이 만나 융합하여 연구 참여자는 자신의 억압된 기억과 접촉한다. 내담자의 현재의 사건은 내담자의 과거, 현재, 미래 시간과 연결 되고 그 사건은 연구 참여자의 과거 시간과 융합하여 또 다른 기억 속 장면을 소환한다. 내담자와 치료자의 치료적 관계의 융합은 시간의 혼동 속에서 억압된 기억을 선명하게 재 현한다. 재현은 연구 참여자가 느낀 내담자의 과거와 자신의 과거, 내담자의 현재 상황과 연구 참여자의 기억 속 사건을 그대로의 상태로 자각하게 한다. 온 몸으로 저항하는 치료 자의 과거의 기억은 내담자와의 융합을 통해 꿈처럼 재현되었고 비로소 억압된 기억을 있 는 그대로 받아들이게 된다. 공동전이는 혼돈의 융합을 견디어내고 저항으로부터 분투하여 맞이하게 되는 극적인 순간이다.

3) 구성요소 3. 너와 나의 상처가 만나 치유로 깨어나다

연구 참여자는 자신의 상처를 내담자의 상처를 통해 다시 느끼고 받아들임으로써 치유로 
Journal of Symbols \& Sandplay Therapy, Vol.11 No.2.

표 2. 모래놀이치료자의 공동전이 경험의 구성요소

\begin{tabular}{|c|c|c|}
\hline 구성요소 & 하위구성 요소 & 의미단위 \\
\hline \multirow{15}{*}{$\begin{array}{l}\text { 마음과 마음이 만나 } \\
\text { 교감(交感)하다 }\end{array}$} & \multirow{5}{*}{$\begin{array}{l}\text { (1) 나를 통해 너를 } \\
\text { 느낀다 }\end{array}$} & 모래상자를 창조하는 내담자의 눈빛과 손짓을 통해 절실한 정서를 느낌 \\
\hline & & 피겨와 내담자의 관계가 나를 통해 반사되어 정서로 돌아옴 \\
\hline & & 모래와 접촉하는 내담자의 모습에 고요와 평화가 번짐 \\
\hline & & 함께 하기를 원하는 내담자의 욕구가 모래상자로 나를 초대함 \\
\hline & & 피겨가 전해준 감정을 나를 통해 확인함 \\
\hline & \multirow{5}{*}{$\begin{array}{l}\text { (2) 너를 통해 나를 } \\
\text { 느낀다 }\end{array}$} & 모래상자의 신비로움이 나를 집중하고 몰입하게 함 \\
\hline & & 내담자의 힘듬이 나의 감각을 소름 돋게 함 \\
\hline & & 나의 갈급함이 피겨를 통해 드러남 \\
\hline & & 내담자와 공유한 모호한 두려움으로 인해 내가 먼저 의식으로 전환함 \\
\hline & & 치료실 외부의 관계가 모래상자를 바라보는 나의 시선에 영향을 미침 \\
\hline & \multirow{5}{*}{$\begin{array}{l}\text { (3) 너와 내가 함께 } \\
\text { 느낀다 }\end{array}$} & 내담자와 모래상자 그리고 나의 경계가 사라지고 그 순간 모두가 한 덩어리가 됨 \\
\hline & & 우주 속 빈 상자와 같은 모호하고 무서운 공간에 함께 들어감 \\
\hline & & 함께 하고 있음을 내담자도 나도 감각과 정서를 통해 뿜어냄 \\
\hline & & 어느 순간 모래상자와 내담자와 내가 연결되어 내면의 이야기를 함께 전해줌 \\
\hline & & 모래상자 속 거울이 내담자의 미음과 나의 마음을 함께 비추기 시작함 \\
\hline \multirow{18}{*}{$\begin{array}{l}\text { 기억의 혼돈 속에서 } \\
\text { 우리는 융합(融合)하다 }\end{array}$} & \multirow{4}{*}{$\begin{array}{l}\text { (1) 기억의 혼돈 속 } \\
\text { 으로 빠져들다. }\end{array}$} & 모래상자가 잠든 기억을 깨우고 지진과 같은 갈등과 혼란이 찾아옴 \\
\hline & & 갑자기 떠오른 과거의 기억이 아직은 어떤 감정인지 정리되지 않은 채 모호함 \\
\hline & & 내담자가 연결되어있는 나의 힘든 기억이 심장을 요동치게 함 \\
\hline & & 모래상자로의 초대가 기억 속 혼란스러운 경험을 의식으로 떠오르게 함 \\
\hline & \multirow{4}{*}{$\begin{array}{l}\text { (2) 기억 속 장면이 } \\
\text { 꿈처럼 재현되다. }\end{array}$} & 모래장면이 소환한 기억 속 상처는 크고 깊음 \\
\hline & & 모래상자로부터 촉발된 정서가 몸이 기억하고 있는 과거의 장면을 소환함 \\
\hline & & 과거 기억은 감정을 동반하고 꿈처럼 재현됨 \\
\hline & & 초대받은 모래장면의 혼란스러움이 또 다른 기억 속의 혼란스러움을 드러냄 \\
\hline & \multirow{5}{*}{$\begin{array}{l}\text { (3) 저 너머 시간으 } \\
\text { 로부터 저항하다. }\end{array}$} & $\begin{array}{l}\text { 모래상자에 출현한 피겨가 묻고, 덮고, 아닌 것처럼 살았던 과거의 나를 비추고 } \\
\text { 있음 }\end{array}$ \\
\hline & & 내담자의 조심스러움이 관계의 두려움과 연결되어 내면으로의 하강을 거부함 \\
\hline & & 유능한 나로 남기 위헤 좋은 역할을 선택함 \\
\hline & & 나의 힘든 과거를 떠오르게 하는 내담자의 환경으로부터 도망가고 싶음 \\
\hline & & 직면하지 않는 관계의 불편감을 내담자에게 들키지 않으려고 온 몸으로 방어함 \\
\hline & \multirow{5}{*}{$\begin{array}{l}\text { (4) 시간의 혼돈 속 } \\
\text { 에서 우리를 발견 } \\
\text { 하다 }\end{array}$} & 혼돈 속에서 서로의 과거는 연결되고 비로소 기억 속 사건에 머무르게 됨 \\
\hline & & 시간의 혼돈 속에서 조심스러워하는 내담자와 두려워하는 내가 만남 \\
\hline & & 모호한 과거 시간을 견디고 인내하여 기억 속 장면을 선명하게 보게 됨 \\
\hline & & $\begin{array}{l}\text { 혼돈 속에서 있는 그대로를 바라보니 기억 속의 장면이 무엇을 이야기하는지 알 } \\
\text { 게 됨 }\end{array}$ \\
\hline & & 기억 속의 내 모습은 현재의 내담자 모습과 많이 닮아있음 \\
\hline
\end{tabular}




\begin{tabular}{|c|c|c|}
\hline 구성요소 & 하위구성 요소 & 의미단위 \\
\hline \multirow{15}{*}{$\begin{array}{l}\text { 너와 나의 상처가 만나 } \\
\text { 치유(治㾍)로 깨어나다 }\end{array}$} & \multirow{5}{*}{$\begin{array}{l}\text { (1) 너와 나의 상처가 } \\
\text { 만나 하강하다 }\end{array}$} & 내담자의 상처를 통해 만나게 된 나의 상처는 같은 곳에 뿌리를 두고 있음 \\
\hline & & 내담자의 슬픈 정서가 어린 시절의 슬픈 나를 소환해 함께 울게 함 \\
\hline & & 모래상자에 초대받은 나는 환영받지 못한 나의 상처와 만나서 뒤로 물러남 \\
\hline & & $\begin{array}{l}\text { 두려워서 다가오지 못하는 내담자와 가장자리에서 서있는 내가 서로를 아프게 } \\
\text { 바라봄 }\end{array}$ \\
\hline & & $\begin{array}{l}\text { 상처 있는 곳으로의 하강은 두렵고 힘들지만 용기있는 내담자와 함께 한 발 나 } \\
\text { 아감 }\end{array}$ \\
\hline & \multirow{5}{*}{$\begin{array}{l}\text { (2) 서로의 상처를 알 } \\
\text { 아차리고 이해하다 }\end{array}$} & 기억 속 상처받은 나를 알게 되니 내담자의 상처와 당당하게 대면하게 됨 \\
\hline & & $\begin{array}{l}\text { 내담자의 결핍이 나의 결핍임을 알게 되니 더 이상 상처를 메우려고 애쓰지 } \\
\text { 않음 }\end{array}$ \\
\hline & & 고통의 시간을 견디고 모래 상자 속 피겨가 전해주는 이야기를 듣게 됨 \\
\hline & & 내담자와 나의 상처는 거울처럼 닮아있어서 서로를 그대로 반영함 \\
\hline & & $\begin{array}{l}\text { 관계 속에서 화를 알아차리고 더 이상 관계의 두려움 속에 내담자를 버려두지 } \\
\text { 않음 }\end{array}$ \\
\hline & \multirow{5}{*}{$\begin{array}{l}\text { (3) 치유와 함께 소망 } \\
\text { 으로 깨어나다 }\end{array}$} & 긴 잠에서 깨어나 지금까지 경험하지 못한 새로운 세상을 만남 \\
\hline & & 두려운 비밀이 사라진 곳에 기대와 희망이 빛이 되어 존재함 \\
\hline & & 비눗방울 두 개가 만나 치유를 담은 하나의 큰 동그라미가 됨 \\
\hline & & $\begin{array}{l}\text { 상처가 있는 그 곳에 일상의 에피소드가 생기기 시작하고 지금 여기를 자각하 } \\
\text { 게 함 }\end{array}$ \\
\hline & & 믿음과 인내가 얼어붙은 정신을 녹여 알에서 깨어나는 부화의 순간을 맞이함 \\
\hline
\end{tabular}

나아간다. 돌과 같이 무거운 과거의 아픈 상처는 치료자와 내담자의 치료적 관계 안에서 치유되고 정신의 에너지를 다시 순환하게 하여 현실의 자신과 재회하게 한다. 이를 통해 상처받은 치유자(wounded healer) 원형(archetype)을 회복하고 내담자에게 투사했던 억압된 정 서를 거두어들여 빛을 향해 함께 나아간다. 하강하여 도달한 무의식의 두려움은 희망, 기 대, 설레임 등의 감정으로 전환된다. 심리적 하강과 상승이 교차하고, 그 교차점에서 공동 전이의 순간을 빛과 함께 맞이한다.

\section{2. 공동전이 경험 본질의 일반적 구조}

현상학적 연구에서 말하는 경험의 일반적 구조는 경험의 주제 간의 관계를 의미한다. 주 제별 특성을 시간의 흐름이나 내면의 흐름, 의식의 전환 과정으로 분석하여 통합하는 과정 이다(Giorgi, 1985). 이 과정을 통해 모든 의미 단위들을 일관된 구조로 통합하여 일반화된 문장으로 기술하고자 한다. 
Journal of Symbols \& Sandplay Therapy, Vol.11 No.2.

\section{1) 구성요소 1. 마음과 마음이 만나 교감(交感)하다}

자유롭고 보호받는 공간인 모래놀이치료실로 초대된 두 마음은 교감한다. 마음과 마음의 교감(交感)이 공동전이(co-transference) 경험의 첫 번째 구성요소이다. 교감은 '서로 접촉하여 따라 움직인다'는 뜻이다. 연구 참여자들은 치료자인 자신과 내담자의 느낌에 대한 보고를 진술하였다. 그 정서적 느낌은 나와 타자 즉 치료자와 내담자 사이에 오고가는 정서적 관 계를 표현한 것이다. 두 마음은 접촉하고 타자의 마음을 따라 함께 움직인다. 교감하는 공 동전이의 순간이다. 공동전이의 구성요소인 교감은 세 가지 하위구성요소들의 통합을 통해 더욱 깊어진다.

먼저 '나를 통해 너를 느끼는 과정'은 내담자의 정서를 치료자가 느낀 감정으로 보고하 는 과정이다. 내담자의 간절함, 두려움, 갈망, 의심 등의 다양한 감정이 연구 참여자의 진술 을 통해 드러난다. 내담자를 나를 통해 느끼는 과정에는 전이의 감정이 어느 정도는 포함 되어져 있다.

다음으로 연구 참여자인 치료자가 내담자를 통해 자신의 감정을 표현하는 '너를 통해 나 를 느끼는 과정이다. 자신에게 너무 몰입해서 내담자보다 자신을 먼저 느끼기도 하고, 내 담자의 전이로 부터 소름 돋는 신체 반응을 보고 하기도 하였다. 연구 참여자의 마음이 너 무도 갈급하고 급해서 따라가지 못하고 먼저 움직이기도 한다.

공동전이 심층면담에서는 나를 표현한 느낌의 보고와 너를 표현한 느낌의 보고가 순차적 으로 정렬되지는 않으며 혼재되어있기도 하였다. 이 두과정이 순차적이지는 않지만 분명한 것은 접촉하고 함께 따라 움직인다는 것이다. 또한 '나'의 정서에는 내담자가 접촉하고 있 고, '너'의 정서에는 치료자가 접촉하고 있다. 이런 의미단위들이 모여 교감의 요소를 구성 한다.

마지막 '함께 느끼는' 과정이 교감의 구성요소에서 가장 공동전이(co-transference)의 본질을 함축하고 있다. 두 마음이 접촉하여 함께 움직이기 시작한다. 함께 움직이기도 하고 이 마 음이 저 마음을 따라가기도 한다. 정서가 함께 움직이고 따라가는 교감의 순간을 연구 참 여자들은 다음과 같이 진술하였다.

"그 순간은 굉장히 내담자와 한 덩어리인 듯 했어요",

“공중에 붕 떠있는 빈 상자에 둘이 같이 있는데 외롭고 무서워요", “어느 순간 모래상자 랑 그 장면이 연결이 되어서 함께 느껴져요”

교감을 통해 서로를 느끼고 비로소 공동전이의 장이 펼쳐진다. 공동전이는 교감의 상태 로 서로 접촉하고, 함께 움직이고, 따라 춤추게 한다. 투사를 거두고 진정으로 관계하고 교 감한다. 공동전이는 투사 즉 전이와 함께 있으며 전이와 역전이의 경계가 명확하지 않음을 연구 참여자들의 진술을 통해 알 수 있다. 어느 영역도 의식적 판단으로 거리를 두거나 심 
리적으로 조작할 수 없는 부분이다. 이러한 과정을 거쳐 치료자와 내담자는 교감의 공동전 이로 관계한다.

\section{2) 구성요소 2. 기억의 혼돈 속에서 우리는 융합(融合)하다}

공동전이의 두 번째 구성요소는 과거 시간 속 기억의 융합이다. 내담자의 기억과 치료자 의 기억이 융합하고, 현재의 시간이 과거의 시간과 융합하고, 의식과 암묵적 기억이 융합한 다. 융합(融合)은 '여러 종류의 다른 것들이 녹아서 하나로 합쳐짐'을 뜻하는 말이다. Jung이 원형적 전이를 표현하는 'coniunctio(융합)'와 동일하다.

융합을 위해서는 용해를 위한 그릇이 필요하다. 융합이 일어날 혼돈의 무의식 속으로 연 구 참여자와 내담자는 몸을 담근다. 내담자의 과거, 현재, 미래가 치료자의 과거, 현재, 미 래와 동시적으로 만나고 혼합하여 연구 참여자인 치료자는 과거의 억압된 기억 속으로 빠 져든다.

이 융합은 다른 둘의 혼합을 전제로 하는 의미로써, 두 물질이 만나면 반드시 혼돈을 발 생시킨다. 융합의 첫 과정은 기억의 혼돈이며 연구 참여자들은 이 순간을 '지진', '갈등과 혼란, ‘모호함' 등으로 표현하였다. 진술의 서두에 '갑자기', ‘문득'이라는 단어를 자주 사용 하는 것으로 보아 현재와 과거가 혼합되는 것은 의식적이고 논리적인 작용이라기보다는 불 연 듯 일어나는 무의식적 현상으로 보여진다.

과거의 혼돈 속으로 빠져든 연구 참여자는 억압된 기억을 소환한다. 그들의 말로 표현된 과거는 어제 밤 꿈처럼 생생하다. “몸이 기억하고 있는 것 같아요", "예전 경험이 기억과 함께 떠올라요", “지금 되돌아보니 그 상처가 크고 깊어요”라고 진술하였으며 의식에서는 멀어졌지만 몸은 기억하고 있는 과거의 기억이 재현되었다. 마치 한여름 밤의 꿈처럼 과거 시간은 소환되고 그 꿈은 꿈꾸는 자인 연구 참여자로부터 발생한 것이 아니고 내담자로부 터 촉발된 듯하다. 연구 참여자의 억압된 기억을 소환하고 꿈꾸게 한 그 곳에 내담자의 전 이가 존재한다. 그 과거 기억의 가장 깊은 곳에서 내담자의 과거도 함께 있었다. 실제로도 심층면담의 두 번째 회기에서 자신의 꿈에 대한 보고를 하는 연구 참여자가 있었으며 그 꿈은 ‘흐린 안개 속 풍경'과 ‘물이 채워졌다 빠지는 욕조' 등을 주제를 담고 있었다.

드러난 과거의 억압된 기억은 연구 참여자들의 정서에 저항을 불러일으킨다. 그 저항은 살기위한 몸부림처럼 느껴진다. “묻고 덮고 아닌 것처럼 살았어요”, “그대로 내버려두지 않 죠”, “보여주고 싶지 않아요”라며 온 몸으로 저항한다. 그러나 공동전이의 융합은 내담자와 치료자의 과거, 현재, 미래 시간을 연결하고 공동전이(co-transference)를 통한 연결은 치료자 자신의 내면의 소리를 듣게 한다. 내담자의 현재가 치료자의 과거와 만나면 치료자는 저항 한다. 그러나 두 개의 시간은 융합하게 되고 과거 시간으로부터 해방된다. 억압된 기억 속 의 내가 현재의 나를 받아들이고, 치료자의 과거는 내담자의 현재를 받아들인다. 
Journal of Symbols \& Sandplay Therapy, Vol.11 No.2.

\section{3) 구성요소 3. 너와 나의 상처가 만나 치유(治癒)로 깨어나다}

공동전이의 마지막 구성요소는 상처의 치유이다. 치유는 말 그대로 '병을 낫게 하는 것' 이다. 심리치료의 궁극의 목표이기도 하다. 눈에 보이는 증상 중심의 신체적 질환을 다루 는 것은 아니지만 상담의 공간을 찾는 대부분의 내담자는 치유를 염원한다. 공동전이 경험 의 본질을 담고 있는 치유는 반드시 상처를 포함하고 있다. 연구 참여자들의 진술 내용에 는 치료자의 상처와 내담자의 상처가 맞닿아있고 그 지점에서 치유가 발생한다는 것을 알 려준다.

치유의 첫 번째 하위구성요소는 내담자의 상처와 치료자의 상처가 만나는 것으로 시작된 다. 상처의 만남은 깊은 하강을 예견한다. 낡고 병든 것이 사라지지 않고 어떤 재탄생도 있 을 수 없는 것처럼 하강은 치유로 깨어남을 예견한다. 연구 참여자들의 상처에 대한 진술 은 내담자의 상처에서 시작해서 서서히 자신의 상처를 드러내고 받아들인다. 이처럼 타인 의 상처보다 자신의 상처와 직면하는 것이 누구에게나 어려운 작업일 것이다. 상처를 받아 들이면 정서적으로 하강한다. 또한 모래장면은 '결핍', '죄책감' '의심', ‘무능력' 등의 콤플 렉스와도 직면하도록 한다. 자신의 상처를 내담자를 통해 다시 느끼고 받아들임으로써 낡 은 것들과 이별한다. 공동전이는 이처럼 부정적 역전이 감정이나 콤플렉스와도 연결되어 있다.

상처와 상처가 만나 하강한다는 것은 다음 요소인 깨어남의 순간을 잉태하고 있다. 이는 돌과 같이 무거운 과거의 아픈 상처를 정신의 에너지로 치유하고 새로운 삶과의 재회를 예 견한다. 자신의 상처받은 치유자(wounded healer) 원형(archetype)을 회복하고 내담자에게 투사 했던 억압된 정서도 거두어들여 빛을 향해 나아가기를 두려워하지 않게 되었다. 연구 참여 자들은 이 순간을 “내담자가 깨어나는 듯한 느낌을 받았어요", "기대, 희망 그런 것들이 있 어요", “알을 깨고 나오는 그런 느낌" 등으로 표현하였다. 비로소 희망, 기대, 설레임의 감 정들이 생겨나고 재탄생을 예견한다.

깊은 내면의 상처로부터 깨어나 현실로 돌아오게 된다. 연구 참여자인 치료자의 무의식 을 통해 내담자의 전이를 인식하게 되고 이 전이 감정이 무엇인지를 모호하게나마 경험하 게 된다. 전이의 인식은 새로운 자각을 통해 연구 참여자와 내담자를 진정으로 이해하게 한다. 시간이 다시 현재로 돌아오고 연구 참여자들의 진술은 내담자에게 비친 자신에 대한 인식이 포함되어있다. 연구 참여자는 치료자인 자신을 새롭게 인식하면서 동시에 내담자도 새롭게 알아차렸다. 공동전이가 어느 한 쪽 방향으로만 작용하지 않는 다는 것을 상기하게 된다. 전이와 역전이는 치료적 관계에 지속적으로 영향을 미치고 있으며 공동전이도 언제 어디서나 일어날 수 있는 순간이다.

공동전이(co-transference)의 본질을 구성하고 있는 교감(交感), 융합(融合), 치유(治療)는 각각 의 독특한 하위 구성요소를 가지고 있으며 그 과정은 순차적이기도 하고 혼재되어 있기도 
하다. 그러나 순서와 상관없이 하위 구성요소들은 유기적으로 관계하고 살아 숨 쉬는 요소 들이며 모두가 함께 존재할 때 공동전이는 치료적 관계로 기능하게 된다. 물론 공동전이의 세 개의 구성요소도 서로 긴밀하게 연결되어 있으며 하위 구성요소를 공유하기도 한다.

\section{$\mathrm{IV}$. 결 론}

공동전이(co-transference)는 모래놀이치료의 치료적 관계 형성의 필수 요소이며 내담자와 치료자 간에 동시적이고 순간적으로 일어나는 무의식적 유대의 개념이다. 또한 순차적인 전이, 역전이 개념을 포괄한다. 일반적인 수퍼비젼이나 사례회의에서는 내담자의 정신 역동 을 중심에 두고 전이를 분석하여 치료에 유용한 맥락을 제공하는 것에 포커스가 맞추어져 있으며 치료자 역시 자신의 감정 상태에 몰입되어져 있는 것을 부정적 역전이 현상으로 인 식하여 감정 전이를 깊이 다루기가 쉽지 않다. 이러한 이유로 치료자의 치료적 관계에서의 특별한 감정 또는 강렬한 전이감에 대해서는 충분히 다루지 못한다.

모래놀이치료자가 상담의 장(field)에서 내담자와의 함께 창조하는 공동전이의 경험을 탐 색하고 구조화하여 그 경험의 본질적 의미가 무엇인가를 알고자함이 본 연구의 목적이다.

본 연구는 모래놀이치료자의 공동전이 경험을 치료자 의식의 지향성을 추적하여 그 현상 에 대한 순수 경험, 본질적인 경험의 본질을 현상학적 질적 연구 방법으로 접근한다. 이러 한 연구 수행을 위해서 질적 연구 방법 중 특히 경험의 의미와 본질을 기술하는데 초점을 둔 Giorgi의 현상학적 연구 방법을 사용하였다.

모래놀이치료자 7명의 사례를 통해 모래놀이치료에서의 공동전이 경험의 본질적 의미를 도출하였다. 연구 참여자의 심층면담 텍스트를 기반으로 경험의 본질을 현상학적 질적 연 구 방법으로 분석하였다. 연구 참여자들의 진술 중에 의미의 전환이 이루어지는 부분을 표 시하여 800 여개의 의미단위를 도출하여 그 중에 반복되거나 맥락에서 벗어난 의미단위를 제외한 540 개의 의미단위를 최종 구조 분석의 의미 단위로 사용하였다. 연구 참여자들의 의미단위를 통합하고 비교하여 공통의 요소를 다시 116 개의 의미로 요약하였다. 이렇게 도 출된 중심의미를 바탕으로 3 개의 구성요소와 10 개의 하위구성요소를 구조화하였다. 10 개의 하위 구성요소는 48 개의 의미 단위를 포함하고 있다.

3 개의 구성요소는 공동전이 경험의 본질을 의미한다. <마음과 마음이 만나 교감하다>는 내담자와 치료자의 두 마음은 접촉하고 서로의 마음을 따라 함께 움직이는 것을 의미한다. 정서적으로 공감하는 교감의 순간이다. 연구 참여자들은 치료자와 내담자 사이의 깊은 공 감을 공동전이의 본질 의미로 진술하였다. <기억의 혼돈 속에서 우리는 융합하다>는 연구 참여자의 과거, 현재 시간과 내담자의 과거, 현재가 교차하여 과거의 기억 속으로 융합한 
Journal of Symbols \& Sandplay Therapy, Vol.11 No.2.

다. 혼돈이 함께하는 내담자와의 융합을 연구 참여자들은 공동전이의 중요한 의미로 드러 내주었으며 그 시간은 융합된 시간이며, 기억 또한 내담자와의 융합의 토대 위에 펼쳐진다. 기억의 융합은 연구 참여자에게 과거로의 여정을 허락하였으며 진술의 많은 부분이 연구 참여자 자신의 과거 시간에 할애하였다. <너의 상처와 나의 상처가 만나 치유로 깨어나 다>는 내담자의 상처인 주호소의 주제로부터 시작하였으나 연구 참여자는 내담자와 맞닿 아있는 자신의 상처와도 만나게 되었다. 상처가 만난 자리에 치유의 원형적 에너지가 배열 되었다.

공동전이는 교감(交感), 융합(融合), 치유(治瘾)의 일반적인 구조로도 통합되고 이해되어진 다. 연구 참여자의 공동전이에 대한 심층면담은 시간과 공간을 초월하여 모래 장면과 내담 자를 진술의 중심에 세워두었으며 공동전이를 통해 내담자와 교감하고, 모래상자와 융합하 며 자신의 상처를 통해 치유로 나아간다.

모래놀이치료자가 모래 상자를 창조하는 내담자와 조우하면서 신성한 경외감을 느끼기도 하고, 말이 전해주지 못하는 내면의 고통을 깊이 공감하기도 하고, 내담자의 전이에 오염되 어 무의식적 혼란 상태에 빠지기도 한다. 이러한 원형적 융합, 가치로운 혼합인 공동전이가 치료적 관계의 변화를 가져오고 치유로 연결됨을 모래놀이치료자는 심층 면담을 통해 그들 의 목소리로 생생하게 들려주었다.

연구 참여자들로부터 기술된 공동전이의 구성요소는 일련의 사건이라기보다는 연속성의 의미를 지니고 있었으며 어느 부분을 특정지어 공동전이의 경계로 두는 것보다 동시적인 과정으로 이해되는 것이 바람직 할 것이다. 연구 참여자는 심층면담을 통해 공동전이의 경 험을 진술하면서 치료 상황과는 별개로 자신의 과거 또는 무의식으로의 초대를 기꺼이 허 락해주었다. 이런 연구 참여자의 내면으로의 연결이 공동전이의 선제적인 조건임을 본 연 구는 경험의 구성요소를 통해 보여준다.

공동전이 경험은 치료자와 내담자가 만나 무의식적으로 관계하고 다시 그 꿈과 같은 만 남에서 깨어나 다시 자신으로 돌아오는 구조를 가지고 있다. 자신을 새롭게 자각한 치료자 는 내담자를 진정으로 사랑하게 되고, 더 깊게 이해하고, 동정(sympathy)으로부터 해방된다. 연구 참여자들이 경험한 공동전이는 전이의 해석으로 부터 멀어져서 무의식적 기억, 감각, 정서를 총 동원하여 소통하는 내담자와의 상호작용이다.

본 연구를 통해 모래놀이치료자가 경험한 공동전이라는 강렬한 치료적 순간을 심리치료 의 연장선에서 벗어나 치료자 자신에게 어떠한 일, 어떠한 사건인지를 통찰할 수 있는 기 회를 제공하고 나아가 테메노스(Temenos)의 공간인 모래놀이치료실에서 모래상자, 그 앞에 존재하는 심리적 용기(容器)인 모래놀이치료자의 자기 성찰의 기회를 가지는 것에 그 의의 를 덧붙이고자 한다.

마지막으로 본 연구의 제한점과 후속 연구를 위한 제언을 하고자 한다. 본 연구의 연구 
참여자 임상 경력의 범위가 모래놀이치료자의 임상 경력의 넓은 폭을 다 수용하지 못 한 한계가 존재함으로, 임상 경력에 따른 공동전이 경험의 다양한 이해를 바탕으로 한 연구가 확충되어야 할 필요가 있다. 이와 더불어 치료자를 연구 참여자로 수행한 본 연구가 밑거 름이 되어 내담자의 상담 경험의 장 또는 내담자와 치료자 간의 상호교류적인 상담 경험의 장 안에서 공동전이의 본질을 탐구하는 것도 지속적으로 이루어져야 할 연구 주제가 될 것 이다.

\section{참고문헌}

김분한, 김금자, 박인숙, 이금재, 김진경 (1999). 현상학적 연구방법의 비교고찰. 대한간호학회

지, 29(6), 1208-1220.

김준혜, 안현의 (2013). 상담자 발달수준, 마음 챙김 및 역전이 관리능력과의 관계. 인간이해

34(2), 95-109.

김현주, 김광웅 (2007). 아동상담자의 자아탄력성 및 스트레스 대처 방식이 역전이 관리 능

력에 미치는 영향. 놀이치료연구-한국놀이치료학회, 10(1), 35-46.

이근호 (2007). 질적 연구 방법론으로서의 현상학. 교육인류학연구, 10(2), 41-64.

이영순 (2010). 상담일반: 초보 상담자들의 어려움과 역전이 관리능력 및 상담성과 간의 관

계. 상담학연구, 11(3), 1021-1035.

임고운, 김지현 (2008). 상담일반: 상담자 발달수준 및 역전이 활용과 상담성과. 상담학연구,

9(3), 987-1006.

장미경 (2017). 분석심리학적 모래놀이치료. 서울: 학지사.

최명식 (2005). 역전이 활용 척도의 개발 및 타당도 연구. 연세대학교 박사학위논문.

최지영, 이영애 (2009). 놀이치료자의 자기효능감 및 사회적 지지와 역전이 관리능력과의 관

계. 한국놀이치료학회지 (놀이치료연구) 12(3), 31-45.

황인호 (2005). 상담자의 자기효능감과 역전이 행동 및 상담협력관계가 상담만족도에 미치

는 영향. 한국심리학회지: 상담 및 심리치료, 17(3), 547-563.

Bradway, K. (1991). Transference and countertransference in sandplay therapy. Journal of sandplay therapy, $1(1)$.

Bradway, K., \& McCoard, B. (1997). Sandplay-silent workshop of the psyche. London: Routledge.

Friedman, H. S., \& Mitchell, R. R. (2007/2011). 모래놀이치료 슈퍼비젼 (Supervision of sandplay therapy) (장미경, 이미애, 이상희, 채경선, 홍은주 역). 한국임상모래 놀이치료학회.

Giorgi. A. (1985). Phenomenological and psychological research. Pittsburgh, PA: Duquesne University Press. 
Journal of Symbols \& Sandplay Therapy, Vol.11 No.2.

Giorgi, A. (1997). The theory, practice, and evaluation of the phenomenology methods a qualitative research, Journal of Phenomenology, 28, 235-260.

Giorgi, A, (2004). Qualitative research methodology: Advanced workshop on the descriptive phenomenological Method, 2004 한국질적연구센터 워크솝 자료.

Jacoby, M. (1990). Individuation and narcissism: The psychology of self in Jung and Kohut. London/New York: Routlege.

Jung, C. G. (1966). Psychology of the transference. Princeton, NJ: Princeton University Press.

Jung, C. G. (1966/1993). Principles of practical psychotherapy. In C. G. Jung, The Practice of psychotherapy (2nd ed.). East Susses: Routledge.

Kalff, D. (1980). Sandplay: A psychotherapeutic approach to the psyche. Cloverdale, CA: Temenos Press.

Montecchi, F. (1991). Hands that talk and analytical listening. Journal of Sandplay Therapy, \&(1), 25-67.

Moustakas, C. (1994). Phenomenological research method. Thousand Oaks, CA: Sage Publications.

Schore, A. N. (2003). Affect regulation and disorder of the self. New York: W. W. Norton \& Co., Inc.

Schore, A. N. (2012). The science of the art of psychotherapy. New York: W. W. Norton \& Co., Inc.

Seidman, I. (1998). Interviewing as qualitative research. NY: Teachers College Press.

Stern, D. (2008). The clinical relevance of infancy: A progress report. Infant Mental Health, 29(3), $177-188$.

Stewart, L. H., \& Chodorow, J. (2000). Sandplay and active imagination. The San Francisco Jung Institute Library Journal, 18(3), 41-49.

Tesch, R. (1990). Qualitative research: Analysis types and software tools. New York: Falmer Press.

Turner, B. A. (2005/2009). 모래놀이치료핸드북 (The Handbook of sandplay therapy) (김태련 외 역). 서울: 학지사.

van Manen, M. (1990/1994). 체험 연구: 해석학적 현상학의 인간과학 연구방법론 (Researching lived experience: Human science for an action sensitive pedagogy) (신경림, 안규남 역). 서울: 동녁.

투고일 : 2020. 09. 30

수정일 : 2020. 11. 19

게재확정일 : 2020. 12. 21 